\title{
BEYOND BROWN: EVALUATING EQUALTTY IN HIGHER EDUCATION
}

\author{
JAMES A. WASHBURN \\ INTRODUCTION
}

[T] he Negro needs neither segregated schools nor mixed schools. What he needs is Education. What he must remember is that there is no magic, either in mixed schools or in segregated schools. A mixed school with poor and unsympathetic teachers, with hostile public opinion, and no teaching of truth concerning black folk, is bad. A segregated school with ignorant placeholders, inadequate equipment, poor salaries, and wretched housing, is equally bad. Other things being equal, the mixed school is the broader, more natural basis for the education of all youth. It gives wider contacts; it inspires greater self-confidence; and suppresses the imferiority complex. But other things seldom are equal, and in that case, Sympathy, Knowledge, and the Truth, outweigh all that the mixed school can offer. ${ }^{1}$

We conclude that in the field of public education the doctrine of "separate but equal" has no place. Separate educational facilities are inherently unequal. ${ }^{2}$

Representing two opposing perspectives, these historic passages are the foundation for the current debate over the extent to which the goal of racial integration should govern the policies of formerly segregated schools. The ideal expressed in the U.S. Su-

1. W.E.B. Du Bois, Does the Negro Need Separate Schools?, 4 J. NEGro EduC. 328, 335 (1935), reprinted in W.E.B. DU BoIs: A READER 286 (Meyer Weinberg ed., 1970). John W. Davis, the primary attorney opposing NAACP attorney Thurgood Marshall in the oral arguments of Brown v. Board of Education before the U.S. Supreme Court, used a similar quotation from Du Bois to close his argument: "We shall get a finer, better balance of spirit; an infinitely more capable and rounded personality by putting children in schools where they are wanted, and where they are happy and inspired, than in thrusting them into hells where they are ridiculed and hated." See CARL T. ROWAN, DREAM MAKERS, DREAM BREAKERS: THE WORLD OF JUSTICE THURGOOD MARSHALL 200 (1993).

2. Brown v. Board of Educ., 347 U.S. 483, 495 (1954). 
preme Court's opimion in Brown v. Board of Education ${ }^{3}$-that integrated schools always provide a better education for black students thàn segregated ones-clashes with W.E.B. Du Bois's implication that the hostility between white and black people would always exist. ${ }^{4}$ Given that hostility, Du Bois sought to improve educational opportunities for black youths with much less regard for the "inherent" benefits of integration."

$\mathrm{Du}$ Bois's and the Supreme Court's assertions retain remarkable vitahty in discussions of race and education in the United States today. ${ }^{6}$ The tension between the two perspectives animates the interplay among different ideas about the nature of the constitutional rights and remedies that Brown so boldly asserted. The tension is particularly acute because American society remains largely segregated despite the constitutional mandate of Brown and later desegregation cases to integrate the public schools. ${ }^{7} \mathrm{~A}$ comparison of the two views is especially perplexing in light of empirical studies suggesting that forcibly integrated environments may result in worse educational outcomes for black students than segregated situations. ${ }^{8}$ To what extent should the integrationist ideal espoused in Brown serve as the standard for the equality of educational opportunities in areas where segregation once was the norm?

To be sure, the integrationist ideal remains the constitutional cornerstone of the Supreme Court's treatment of racial issues in

3. Id.

4. See text accompanying note 1 .

5. See, e.g., W.E.B. DU BOIs, Whither Now and Why, in THE EDUCATION OF BLACK PEOPLE 149, 149-53 (Herbert Aptheker ed., 1973) (advocating that African-Americans retain a distinctive culture by maintaining predominantly black schools and colleges).

6. See, e.g., United States v. Fordice, 112 S. Ct. 2727 (1992); Board of Educ. v. Dowell, 111 S. Ct. 630 (1991); JEAN L. PREeR, LAwYers V. EduCators: BlaCK COLLEGES AND DESEGREGation IN PUbliC HIGHER EDUCATION (1982); Derrick A. Bell, Jr., Racism Is Here to Stay: Now What?, 35 How. LJ. 79 (1991); Richard Cummings, All-Male Black Schools: Equal Protection, the New Separatism and Brown v. Board of Education, 20 HAstings CONST. L.Q. 725 (1993); Drew S. Days, III, Brown Blues: Rethinking the Integrative Ideal, 34 WM. \& MARY L. REv. 53 (1992); Sonia R. Jarvis, Brown and the Afrocentric Curricultum, 101 YALE L.J. 1285 (1992).

7. See, e.g., Dowell, 111 S. Ct. at 636-38 (refusing to reinstate court control over a school district that had not intentionally discriminated against blacks since 1961); see also William Celis 3d, Study Finds Rising Concentration of Black and Hispanic Students, N.Y. TiMES, Dec. 14, 1993, at A1 (noting the Harvard Project On School Desegregation study, which determined that racial segregation in schools is rising due to substantial residential segregation in many areas).

8. See infra notes $\mathbf{1 7 3 - 7 5}$ and accompanying text. 
education. ${ }^{9}$ Despite massive resistance, the Court, through Brown and its progeny, has completely metamorphosed the character of elementary and secondary public education in the South. ${ }^{10}$ By declaring that separate educational systems for whites and blacks were "inherently" unequal, the Brown decision ensured that a school district that inaintained dual school systems for whites and blacks could not claim that blacks were receiving an equal education. Later, after years of frustration over southern school boards' lack of progress in effectively integrating their schools, the Supreme Court, in Green v. County School Board, ${ }^{11}$ required that affirmative steps be taken to eliminate racially identifiable schools, making explicit Brown's mandate that segregation by law would not be tolerated. ${ }^{12}$ By the late 1960 s, the racial identifiability of eleinentary and secondary schools had becoine tantamount to a showing that a school board had not gone far enough in disestabhshing its dual school system. ${ }^{13}$

9. See infra Parts' I-II.

10. Plaintiffs who sued school systems that were not intentionally (de jure) segregated, but were segregated in fact (de facto), were denied relief by the courts. See, e.g., Columbus Bd. of Educ. v. Penick, 443 U.S. 449 (1979); Dayton Bd. of Educ. v. Brinkman, 433 U.S. 406 (1977); see also WILLIAM B. LOCKHART ET AL., CONSTITUTIONAL LAW 1240-58 (1991) (distinguishing de jure and de facto discrimination generally). Thus, the majority of successful desegregation efforts focused on school districts with facially segregative policies, most of which were located in the South, where the effects of segregation were most acute.

There were numerous exceptions. The lead case in Brown dealt with segregation in the Topeka, Kansas school system. See also Milliken v. Bradley, 418 U.S. 717 (1974) (Detroit, Michigan); Keyes v. School Dist., 413 U.S. 189 (1973) (Denver, Colorado); Morgan v. Hennigan, 379 F. Supp. 410 (D. Mass.) (Boston, Massachusetts), aff $d$ sub nom. Morgan v. Kerrigan, 509 F.2d 580 (1st Cir. 1974), cert. denied, 421 U.S. 963 (1975). Virtually all the publicly funded historically black colleges that are the focus of this Note, however, are located in the South; many were founded to educate former slaves during Reconstruction. See Gil Kujovich, Equal Opportunity in Higher Education and the Black Public College: The Era of Separate but Equal, 72 MinN. L. REV. 29 (1987).

11. 391 U.S. 430 (1968).

12. Justice Brennan's language could not have been more imperative.

[Respondents] operating state-compelled dual systems [are] . . . charged with the affirmative duty to take whatever steps might be necessary to convert to a unitary system in which racial discrimination would be eliminated root and branch .... . The burden on a school board today is to come forward with a plan that promises realistically to work, and promises realistically to work now.

Id. at 437-38, 439; see also Swann v. Charlotte-Mecklenburg Bd. of Educ., 402 U.S. 1 (1971) (setting out the general types of remedies that courts may provide to integrate school systems).

13. See infra Section $\mathrm{I}(\mathrm{B})$. 
Even in states whose federal courts were most active in desegregating local school districts, colleges and universities have been maintained that are clearly racially identifiable, a legacy of the pre-Brown days of state-coinpelled segregation. ${ }^{14}$ The black colleges and umversities, established to provide segregated facilities for higher education, are undoubtedly "vestiges"15 of the discriminatory education system. ${ }^{16}$ In 1992, the Supreme Court extended the integrationist ideal to those public university systems. ${ }^{17}$

In United States $v$. Fordice, ${ }^{18}$ the Court determined that Mississippi had the affirmative duty to remove all vestiges of the state's segregated past from its higher education system. ${ }^{19}$ Seeing that certain colleges were historically segregated and racially identifiable, the Court found that the facially race-neutral policies enacted after the formal desegregation of Mississippi's colleges perpetuated the dual nature of the college system. ${ }^{20}$ The Court held that the state's facially nondiscriminatory policies were insufficient to remedy prior intentional discrimination and that Mississippi must develop a plan to reduce the racial identifiability of its colleges. $^{21}$

This Note asserts that the underlying integrationist ideal of Brown does not necessarily flow from the principles of the Fourteenth Amendment and in fact may demand inore integration than is constitutionally required. ${ }^{22}$ This overstepping can be traced to

14. Interestingly, the first successful challenges to Jim Crow educational systems came in the area of higher education. See Sipuel v. Board of Regents, 332 U.S. 631 (1948); Missouri ex rel. Gaines v. Canada, 305 U.S. 337 (1938).

15. See Swann, 402 U.S. at 15.

16. See PREER, supra note 6, at 233-41 (summarizing the history of state-supported predominantly black colleges and the NAACP Legal Defense Fund's efforts to end discrimination in higher education); Kujovich, supra note 10, at 44-113 (chronicling the conditions at segregated black colleges and universities in the years before the Supreme Court limited the doctrine of separate but equal).

17. United States v. Fordice, 112 S. Ct. 2727 (1992).

18. Id.

19. This holding did not affect private institutions because the Equal Protection Clause of the Fourteenth Amendment governs only state action. See U.S. CONST. amend. XIV, § 1 ("No State shall ... deny to any person within its jurisdiction the equal protection of the laws.") (emphasis added); The Civil Rights Cases, 109 U.S. 3, 11 (1883).

20. Fordice, 112 S. Ct. at 2736.

21. Id. at 2735-43. For a discussion of this decision, see infra Part II.

22. This Note does not espouse a purely "color-blind" critique of desegregation jurisprudence, as other authors have done. Those critics believe that all the Constitution requires are facially nondiscriminatory policies or policies that are not intended to segregate or discriminate. See, e.g., ROBERT H. BORK, THE TEMPTING OF AMERICA 74-84 (1990); 
the Court's decision in Brown, in which Chief Justice Warren failed to explain precisely why dual school systems violate the Fourteenth Amendment, that "[s]eparate educational facilities are inherently unequal." 23 This Note argues that separate schools are not inherently unequal; the inferiority described in Brown should be attributed to the notions of white superiority ingrained in the social structures that once demanded mandatory segregation.

By only implicitly acknowledging this overarching notion of white superiority, the Court mistakenly equated integration with providing equal educational opportunity. ${ }^{24}$ In so doing, the Court created a basis in constitutional law for the remedies authorized in Fordice, which will remake the university systems of southern states, possibly to the detriment of blacks. ${ }^{25}$ The racial identifiability, or "separateness," of a college should not create an irrebuttable presumption of injury to black students. Instead, courts should evaluate the circumstances surrounding racial identifiability and specifically determine whether a real constitutional injury exists before authorizing remedies to reduce the identifiability.

Part I of this Note offers a discussion and critique of the entrenchment of integration and the elimination of racially identifiable schools as the accepted standard for determining whether a state or school district has fulfilled its duty to provide equal educational opportumities. Part II examines the federal courts' decisions in higher education discrimination cases generally and discusses how the Court's decision in Fordice reconfigures existing constitutional standards to make higher education institutions conform with Green. This Part specifically traces Mississippi's efforts to

ANDREW Kull, THE COLOR-Blind CONSTITUTION 151-63 (1992); Herbert Wechsler, Toward Neutral Principles of Constitutional Law, 73 HARV. L. REV. 1 (1959); see also Robert H. Bork, Neutral Principles and Some First Amendment Problems, 47 IND. L.J. 1, 14-15 (1971). Justice Scalia apparently also espouses this view. See, e.g., Fordice, $112 \mathrm{~S}$. Ct. at 2750-51 (Scalia, J., concurring in part and dissenting in part). Rather, this Note urges courts to look behind the rationales of the seminal cases of Brown and Green and reconsider whether racial identifiability traced from de jure segregation should be dispositive evidence of continuing violations of equal protection rights. See infra Section III(B).

23. Brown v. Board of Educ., 347 U.S. 483, 495 (1954).

24. The political decision Chief Justice Warren made in crafting the opinion in Brown had an enormously positive effect on the eradication of inequality in southern education. The incomplete analysis supporting the Court's equation of integrated environments to equality of educational opportunity, however, has led to an overstepping of constitutional boundaries in later decisions. See infra Parts I, III.

25. See infra Part III. 
dismantle its dual higher education system and the Supreme Court's evaluation of those efforts. Part III evaluates the potential effects of mandatory integration on southern colleges, especially with regard to the opportunities of black students. Finally, Part III provides an alternative means for remedying a state's past discrimination. Rather than use racial identifiability as a surrogate for black students' constitutional injuries, this Note urges courts to determine specifically whether states are providing equal opportuinties, regardless of whether these states choose to integrate their campuses affirmatively or to permit students to gravitate toward racially identifiable schools.

\section{BROWN, GREEN, AND THE CONSTITUTIONALIZATION OF INTEGRATION}

Ushering in a new era in the law's treatment of blacks under the Constitution, the U.S. Supreme Court in Brown v. Board of Education focused on the injuries that blacks suffered under a regime of segregation. ${ }^{26}$ In doing so, it avoided recognizing a constitutional violation for other segregative laws, preferring to limit to education its declaration that racial separation would always result in a constitutionally actionable injury. By creating a proxy for a constitutional violation when there were intentional acts that led to separation, the Court simplified constitutional issues and expanded possible remedies. Later, in Green v. County School Board, the Court made clear that rectifying the constitutional injury armounced in Brown would require remedies sufficient to eliminate racial separation. ${ }^{27}$ For some time, the equation of intentional segregation with constitutional injury was a practical, effective proxy; historically, blacks have been hurt by separation on the basis of race. Yet as times change, the equation of separation and injury may make less sense, invalidating Brown's definition of injury.

\section{A. Brown Forbids Segregation by Mandating Integration}

Racial segregation had a substantial legal pedigree prior to 1954; courts had consistently held that the Equal Protection Clause of the Fourteenth. Amendinent did not forbid segregation on the

26. Brown, 347 U.S. at $493-94$.

27. Green v. County Sch. Bd., 391 U.S. 430, 435-38 (1968). 
basis of race. ${ }^{28}$ The Supreme Court finally broke with that precedent on May 17, 1954, with its decision in Brown v. Board of Education. ${ }^{29}$ Although the schools challenged in Brown were found to be "equalized . . . with respect to buildings, curricula ... . and other 'tangible' factors," ${ }^{30}$ a unanimous Court decreed that racial segregation in public schools violated the Fourteenth Amendment: "To separate [black students] from others of similar age and quahifications solely because of their race generates a feeling of inferiority as to their status in the community that may affect their hearts and minds in a way unlikely ever to be undone." ${ }^{31}$ Consequently, the Court concluded that "in the field of public education the doctrine of 'separate but equal' lias no place. Separate educational facilities are inherently unequal." 32

The Court did not base this bar to racial segregation in schools on a revised understanding of the Equal Protection Clause. It instead relied on psychological tests that determined that black children were burdened by a sense of inferiority and were "deprive[d] ... of some of the benefits they would receive in a racial[ly] integrated school system." ${ }^{33}$ Importantly, the decision

28. For those trying to prohibit state-sponsored racial segregation in the schools or anywhere else, the major legal obstacle was the Supreme Court's decision in Plessy v. Ferguson, 163 U.S. 537 (1896). According to the eight-Justice majority, the "fallacy" of the argument challenging a law that required separate but equal accommodations for black and white rail passengers was "the assumption that the enforced separation of the two races stamps the colored race with a badge of inferiority. If this be so, it is not by reason of anything found in the act, but solely because the colored race chooses to put that construction upon it." Id. at 551. To the Justices in Plessy, the Fourteenth Amendment did not go so far as to outlaw segregation. See RICHARD KLUGER, SIMPLE JUSTICE 74-81 (1975).

29. 347 U.S. 483 (1954). For a treatment of how the NAACP legal relief organization plotted to bring down the regime of separate but equal in public education, see MARK V. TUSHNET, THE NAACP'S LEgal Strategy Against SEgRegated EduCATION, 1925-1950 (1987).

30. Brown, 347 U.S. at 492.

31. Id. at 494 .

32. Id. at 495 .

33. Id. (quoting Belton v. Gebhart, 87 A.2d 862, 865 (Del. Ch. 1952)) (second alteration in original). The Equal Protection Clause had been used before to assert the illegality of racial segregation. One of the earliest and most powerful pronunciations of this use came from Justice John Marshall Harlan, Plessy's lone dissenter.

Every one knows that the statute in question had its origin in the purpose, not so much to exclude white persons from railroad cars occupied by blacks, as to exclude colored people from coaches occupied by or assigned to white persons .... 
failed to declare racial segregation unconstitutional on its face. Rather, by relying on the pernicious effects of segregation, the Court in Brown acknowledged at least the theoretical possibility that statutory racial segregation might not violate the Fourteenth Amendment. If segregative conditions were found not to cause any feelings of inferiority, following the logic of Brown, a law mandating racial segregation would be constitutional. ${ }^{34}$ Thus, Chief Justice Warren's opinion was twice unfortunate: it implicitly denied that racial segregation, $m$ and of itself, violated the Fourteenth Amendment, ${ }^{35}$ and it tied the constitutionality of the segregation to the injuries perceived by the its victims. ${ }^{36}$

The Court chose this path despite overwhelming evidence that segregation by law in the South was intended to maintain the structure of white social superiority and to deny blacks the equal protection of the law. As historian C. Vann Woodward noted in 1955, "[I]t was . . . clear that the Negro would be effectively dis-

.... There is no caste here. Our Constitution is color-blind, and neither knows nor tolerates classes among citizens. In respect of civil rights, all citizens are equal before the law.

Plessy v. Ferguson, 163 U.S. 537, 557, 559 (1896) (Harlan, J., dissenting).

34. See KULL, supra note 22, at 154; ("The constitutionality of racial segregation was left hostage, moreover, to modern authority in the social sciences. Should subsequent, more modern authority question the sociological wisdom of $1954 \ldots$ the authority of the constitutional rule ... would be to that extent diminished.").

35. The Court in other contexts has recognized that racial segregation may contradict the Fourteenth Amendment. See, e.g., United States v. Carolene Products Co., 304 U.S. 144, 153 n.4 (1938). Other commentators have agreed with this approach. See Charles L. Black, Jr., The Lawfulness of the Segregation Decisions, 69 YALE L.J. 421, 421-28 (1960); Louis H. Pollak, Racial Discrimination and Judicial Integrity: A Reply to Professor Wechsler, 108 U. PA. L. REV. 1, 27, 29-30 (1960).

36. See J. HARVIE WILKINSON III, From BRowN to BAKKE 32 (1979). Any number of reasons have been offered to explain why the Court resolved to announce this very controversial holding so ambiguously. J. Harvie Wilkinson points to three. First, as a former politician, Chief Justice Warren "felt a need ... to remain comprehensible to common men .... He . . . purposely wrote a short opinion so that any layman interested in the problem could read the entire opinion [instead of getting just] a little piece here and a little piece there." Id. at 30 (quoting HENRY J. ABRAHAM, FREEDOM AND THE COURT 372 n.90 ( $3 \mathrm{~d}$ ed. 1977)). Warren also purposely made the opinion bland in an effort to gain the unanimity of the Court, making the Court's decision more effective. "To speak with one voice was to speak with force and finality; to speak otherwise was but to lend comfort to an enemy already in prey." Id. Finally, the Court's opinion was tailored to avoid, as much as possible, inflaming the South, to which Brown's pronouncements were so obviously directed. Not only were three southerners on the bench but "a prolonged exegesis on the virtues of integration or the evils of its opposite might, the justices feared, bring forth once more the drums and bugles of the old Confederacy. Temperance and tact were the order of the day." Id. at 31; see KLUGER, supra note 28, at 696 (narrating a similar history). 
franchised throughout the South, ... and that neither equality nor aspirations for equality in any department of life were for him. The public symbols and constant reminders of his inferior position were the segregation statutes." 37 The separation of the races did not indicate equality between them; in some southern states other laws made it actionable defamation to call a white man a Negro and actionable humihation to place a white person in a railroad car reserved for blacks. ${ }^{38}$ The regime of segregation thus had as its purpose the maintenance of a society in which whites were superior to blacks, a purpose that contravenes the established meaning of the Fourteenth Amendment. ${ }^{39}$

Despite the strength of this equal protection argument, the Court chose to rely on the effects of segregation: the "sense of inferiority" that a segregated education created in black children. Chief Justice Warren thus avoided the nexus between the laws mandating segregation and the constitutional violation. ${ }^{40}$ The Brown decision makes hittle sense from a constitutional perspective because the Court made no connection between the violation and

37. C. Vann Woodward, The Strange Career of Jim Crow 6-7 (3d ed. 1974).

38. Black, supra note 35 , at 426,427 . The disparity in conditions for whites and blacks, determined by the laws of separation, led Professor Black to note,

Segregation in the South grew up and is kept going because and only because the white race has wanted it that way-an incontrovertible fact which in itself hardly consorts with equality. This fact perhaps more than any other confirms the picture which a casual or deep observer is likely to form of the life of a southern community-a picture not of mutual separation of whites and Negroes, but of one in-group enjoying full normal communal life and one out-group that is barred from this life and forced into an inferior life of its own.

Id. at 425. See generally RoBERT PENN WARREN, SEGREGATION (1956) (reporting the attitudes of southerners toward race relations in the 1950s, gleaned from a variety of personal encounters).

39. See Charles Lawrence, "One More River to Cross," in SHAdes of Brown: NEw Perspectives on SCHOOL Desegregation 49 (Derrick Bell ed., 1980). As Lawrence notes, "Segregation violates the equal protection clause of the fourteenth amendment not because there is no rational relationship between the classification and the purpose-it is a supremely rational system-but because its purpose is illegitimate." Id. at 51 .

40. But see Alexander M. Bickel, The Original Understanding and the Segregation Decision, 69 HARv. L. REv. 1 (1955). Bickel, fresh from a clerkship on the Supreme Court, argued that the original understanding of the Fourteenth Amendment did not contemplate the elimination of segregation. In announcing its decision in Brown in the cursory manner in which it did, the Court avoided choosing one of two embarrassing positions: either declaring itself bound by the legislative history of $\S 1$ of the Fourteenth Amendment, which demonstrated that it was not expected to apply to segregation, or "going counter to what it took to be the original understanding, and of formulating, as it has not often needed to do in the past, an explicit theory rationalizing such a course." Id. at 65 . 
official state action; the act is unconstitutional only because of the injury it caused. ${ }^{41}$ The constitutional violation, according to Brown, lay in the injury resulting from the actual separation of black and white students, assuming official acts had contributed to that separation. The Court in Brown did not declare that those acts were themselves unconstitutional; the injury lay in the separation, not the acts that caused it. $^{42}$

The Court's use of social science evidence to provide a justification for overturning the practice of enforced school segregation represented a wasted opportunity to attack the white superiority inherent in that segregation and to tie the segregation to the broader attitudes of the social culture that supported it. ${ }^{43}$ As Robert Bork notes, "The real rationale for Brown was deeper, and the pretense that it was [based on sociological evidence] cheapened a great moment in constitutional law." ${ }^{44}$ Another commentator concurs: "[The psychological justification was an] essentially artificial explanation of a result reached on fundamentally different

41. Lawreuce, supra note 39, at 51-52. Professor Lawrence continues, "The holding in Brown that racially separate educational facilities are inherently unequal would make most sense if it were simply a recognition of the fact that segregation's purpose is invidious discrimination and that therefore it violates the equal protection clause by definition." Id. at 51 .

The holding in Brown "flew directly in the face of Plessy. ... But [Warren] did so in such an economical and uncontentious way that the basic dishonesty of Plessy was allowed to escape censure and seemed instead to be dismissed as simply no longer fashionable thinking." KLUGER, supra note 28, at 705 . Chief Justice Warren's opinion reads, "Whatever may have been the extent of psychological knowledge at the time of Plessy $v$. Ferguson, this finding is amply supported by modern authority. Any language in Plessy $v$. Ferguson contrary to this finding is rejected." Brown v. Board of Educ., 347 U.S. 483, 494-95 (1954) (citations omitted).

42. This basis, despite its inconsistencies, substantially simplified the prospects for eliminating segregation from schools across the South. Rather than getting bogged down in fact-intensive determinations of whether schools for black students were unequal "in fact," Brown held that these dual school systems were facially unconstitutional. See WILKINSON, supra note 36, at 29, 39; see infra text accompanying notes 190-91.

43. As Justice Brennan has noted in a wholly different context, "A doctrine that is explained as if it were an empirical proposition but for which there is only limited empirical support is both inherently unstable and an easy mark for critics:" United States v. Leon, 468 U.S. 897, 943 (1984) (Brennan, J., dissenting) (dissenting from Court's holding that evidence seized by police officers in good faith but by force of an unconstitutional warrant was admissible at trial).

44. BORK, supra note 22 , at 76 . He continues, "Racial segregation . . w was unconstitutional under all circumstances and had nothing to do with the context of education or the psychological vulnerability of a particular age group. The real meaning of Brown, therefore, was far better than its professed meaning." Id. 
grounds." ${ }^{45}$ The artificiality of the basis of the decision became more obvious as the Court summarily struck down ordinances providing for segregation in parks, ${ }^{46}$ courtrooms, ${ }^{47}$ golf courses ${ }^{48}$ and beaches, ${ }^{49}$ although it cited nothing to indicate that segregation in those contexts caused blacks the lasting psychological scars that school segregation did.

It was obvious from Brown and later decisions that the Supreme Court thought legally enforced segregation was unconstitutional. The injury recognized in Brown, however, resulted from the actual separation, not from the legal act that caused it. That articulation of the constitutional violation led directly to courts' later attempts to remedy segregation by specifically mandating integration.

\section{B. Green and the Implementation of Brown}

Even after the extraordinary pronouncement in Brown, the question of what segregationist school authorities would be required to do to remedy the constitutional violations remained. Facing an angry public determined to maintain the status quo, federal judges in the South were under pressure to minimize the impact of Brown and delay the ultimate goal of integration. ${ }^{50}$ Shortly after the Brown implementation decision ${ }^{51}$ was announced, courts in both the Fourth and Fifth Circuits held that Brown required only. that school districts remove the legal barriers separating black and white students; authorities were not required to actively integrate their schools. ${ }^{52}$ Thus, many school districts were

45. KULL, supra note 22, at 155.

46. See New Orleans City Park Improvement Ass'n v. Detiege, 358 U.S. 54 (1958) (per curiam).

47. See Johnson v. Virginia, 373 U.S. 61 (1963) (per curiam).

48. See Holmes v. Atlanta, 350 U.S. 879 (1955) (per curiam).

49. See Mayor of Baltimore v. Dawson, 350 U.S. 877 (1955) (per curiam).

50. See supra note 36. Despite Chief Justice Warren's desire to make the opinion non-accusatory, the decision in Brown aroused great anxiety throughout the South. See WILKINSON, supra note 36, at 31-33, 62-65 (1979). For a discussion of the pressures that federal district judges faced in implementing Brown, see JACK W. PELTASON, FIFTYEIGHT LONELY MEN (1961).

51. See Brown v. Board of Educ., 349 U.S. 294 (1955). Rather than provide for immediate enforcement of its holding, the Supreme Court in 1955 required school districts to make a "prompt and reasonable start" toward desegregating their schools, id. at 300, and held that schools must make the transition to racial nondiscrimination "with all deliberate speed," id. at 301.

52. The Chief Judge of the Fourth Circuit sat on a panel in a district court case that 
later able to claim compliance with Brown even when most or all of their students attended entirely, although not legally, segregated schools. ${ }^{53}$

In 1968, frustrated with the slow pace of desegregation, the Supreme Court announced in Green v. County School Board ${ }^{54}$ that "freedom-of-choice" plans were not sufficient to fulfill a school district's constitutional duty to black students. ${ }^{55}$ Rather, equal protection required that school boards act affirmatively to remove all vestiges of the former dual system. ${ }^{56}$ The Court thereby rejected

wrote, "Nothing in the Constitution or in the decision of the Supreme Court takes away from the people freedom to choose the schools they attend. The Constitution, in other words, does not require integration. It merely forbids discrimination . . . [andl the use of governmental power to enforce segregation." Briggs v. Elliot, I32 F. Supp. 776, 777 (E.D.S.C. 1955) (three-judge court) (per curiam). This interpretation was echoed in a Fifth Circuit case, Avery v. Wichita Falls Indep. Sch. Dist., 241 F.2d 230, 233-34 (5th Cir.), cert. denied, 353 U.S. 938 (1957), to establish the law over most of the states where legal segregation had been maintained.

53. See Frank T. Read, The Bloodless Revolution: The Role of the Fifth Circuit in the Integration of the Deep South, 32 MERCER L. REV. 1149, 1155-60 (1981). Freedom-ofchoice plans allowed a school district to offer students an ostensible opportunity either to attend a school where they were in the racial minority or remain in the school they had attended under the legally segregated regime. In most school systems, however, not enough students took advantage of this opportunity to integrate effectively the schools. See WILKINSON, supra note 36, at 108-11 (1979); UNITED STATES COMMISSION ON CIVIL RighTS, SOUTHERN SCHOOL. DESEGREGATION 1966-67, at 90-91 (1967).

54. 391 U.S. 430 (1968).

55. Title VI of the Civil Rights Act of 1964 provided that nondiscrimination in student assignment was a condition to the receipt of federal funds. See 42 U.S.C. $\$ 2000 d-6$ (I988). Most school districts were affected by the provision through federal aid programs, such as the subsidy for school lunch programs. School districts could, of course, opt not to follow the regulation and operate without the funds. See infra note 115. Freedom-ofchoice plans were acceptable for Title VI purposes until 1968. See Alexander v. Holmes County Bd. of Educ., 396 U.S. 19 (1969).

56. In so doing, the Court followed the lead of Judge John Minor Wisdom on the Fifth Circuit. See United States v. Jefferson County Bd. of Educ., 380 F.2d 385 (5th Cir.) (en banc) (per curiam), cert. denied, 389 U.S. 840 (1967). Judge Wisdom virtually singlehandedly established the affirmative standards of desegregation to give practical effect to the vision of the Brown Court. In Singleton v. Jackson Mun. Separate Sch. Dist., 348 F.2d 729 (5th Cir. 1965), he attacked the distinction between desegregation and integration put forth in Briggs, 132 F. Supp. at 777: "In retrospect, the second Brown opinion clearly imposes on public school authorities the duty to provide an integrated school system." Singleton, 348 F.2d at 730 n.5. Largely through Judge Wisdom's efforts, Brown came to require "an affirmative interpretation of the fourteenth amendment, positively requiring a state to provide unitary school systems that [are] not racially identifiable." Frank T. Read, Judicial Evolution of the Law of School Integration Since Brown v. Board of Education, 39 LAW \& CONTEMP. PROBS., Winter 1975, at 7, $21-22$ (1975). For a discussion of Judge Wisdom's jurisprudence in this area, see WILKINSON, supra note 36 , at 111-14 (1979). 
the distinction between integration and desegregation and required more than race-neutral admissions policies. ${ }^{57}$ As Justice Brennan wrote for the Court, the 'pattern of separate 'white' and 'Negro' schools ... established under compulsion of state laws is [what] ... Brown $I$ declared unconstitutionally denied Negro school children equal protection of the laws." 58 When, after three years of freedom of choice in New Kent County, Virginia, not one white child had transferred to an all-black school and $85 \%$ of black children attended all-black schools, "the school system remain[ed] a dual system." 59

In so holding, the Court in Green emphasized its continuity with the Brown decisions. "Brown II was a call for the dismantling of well-entrenched dual systems tempered by an awareness that complex and multifaceted problems would arise which would require time and flexibility for a successful resolution." Brown called for an educational system in which blacks and whites would be taught together, the Court could no longer tolerate "desegregation plans" under which most children were taught in schools where only one race was present. The announcement of race-neutral policies that perpetuated the status quo was no substitute for integration. "The constitutional rights of Negro school

57. As Judge Wisdom wrote, "In fulfilling this duty it is not enough for school authorities to offer Negro children the opportunity to attend formerly all-white schools. The necessity of overcoming the effects of the dual school system in this circuit requires integration of faculties, facilities, and activities, as well as students." Jefferson County, 380 F.2d at 389. Freedom of choice and the absence of discrimination in student assignment were not enough for the Fifth Circuit. The establishment of race-neutral guidelines would not suffice because the effects of the original constitutional violation, the operation of the dual system, still existed.

In considering whether the school district has met its duty in desegregating its schools, the Jefferson County court suggested using the percentage of blacks and whites in a school as "a rough rule of thumb for measuring the effectiveness of freedom of choice as a useful tool." Id. at 390 . If a choice plan had not reduced the racial identifiability of the schools, said the court, "the school officials . . . have not met the constitutional requirements of the Fourteenth Amendment; they should try other tools." Id. The court added, "Freedom of choice is not the goal in itself. It is a means to an end. . . The governmental objective of this conversion is-educational opportunities on equal terms to all." Id.

58. Green, 391 U.S. at 435 . The mere elimination of compulsory assignment to singlerace schools did not relieve a school district of its duties: " 'Freedom of choice' is not a sacred talisman; it is only a means to a constitutionally required end-the abolition of the system of segregation and its effects." Id. at 440 (quoting Bowman v. County Sch. Bd., 382 F.2d 326, 333 (4th Cir. 1967) (Sobeloff, J., concurring)).

59. Id. at 441 .

60. Id. at 437 . 
children articulated in Brown I permit no less than this; and it was to this end that Brown II commanded school boards to bend their efforts." $" 61$

The effect on lower courts and ultimately on schools was dramatic. Forced into action, courts and school boards across the South $^{62}$ produced desegregation plans that would eliminate the racial identifiability of schools. ${ }^{63}$ The Supreme Court required no less. The relevant information for any plan to be implemented had become how many children of different races would be in school together. As two historians have noted, "The [federal courts] focused more and inore on the 'figures'-what would be the percentage of integration if a particular proposed ... plan were approved? Because of Green's indication that fifteen percent . . . was not enough, the percentage of black children attending previously all-white schools became the critical factor." ${ }^{164}$ Thus actual integration-the interminghing of black and white students in the same classrooms-became the constitutional standard by which all previously segregative school districts were judged, and segregation was eliminated in inost southern schools. ${ }^{65}$

Rather than "rewriting"66 the Brown decision to require

61. Id. at 438. Justice Brennan added, "We bear in mind that the court has not merely the power but the duty to render a decree which will so far as possible eliminate the discriminatory effects of the past as well as bar like discrimination in the future." Id. at 438 n.4 (quoting Louisiana v. United States, 380 U.S. 145, 154 (1965)). Thus, Justice Brennan provided the justification for using the remedial power of the courts to eliminate the vestiges of past discrimination that perpetuated segregation in schools.

62. The NAACP's influence over the challenges to segregation played a major role in the geography of compliance with the Supreme Court's decisions. After the battle in the South was won, a similar wave of desegregation efforts swept through the northern and western states. The Supreme Court's decision in Keyes v. School Dist., 413 U.S. 189 (1973), which held that the existence of intentionally segregative policies in Denver must be remedied by plans that effectively integrate the schools, in particular provided the stimulus for vigorous challenges to school segregation in other parts of the country. See, e.g., Dayton Bd. of Educ. v. Brinkman, 443 U.S. 526 (1979) (Ohio); Columbus Bd. of Educ. v. Penick, 443 U.S. 449 (1979) (Ohio); Milliken v. Bradley, 418 U.S. 717 (1974) (Detroit, Michigan); Morgan v. Hennigan, 379 F. Supp. 410 (D. Mass.) (Boston, Massachusetts), aff'd sub nom. Morgan v. Kerrigan, 509 F.2d 580 (1st Cir. 1974), cert. denied, 421 U.S. 963 (1975).

63. For example, in Montgomery, Alabama, Chief Judge Frank M. Johnson, Jr., handed down a court order that required the school board to achieve racial ratios of faculty at each school that approximated the racial ratio of teachers in the district. See Carr v. Montgomery County Bd. of Educ., 289 F. Supp. 647 (M.D. Ala. 1968), affd sub nom. United States v. Montgomery County Bd. of Educ., 395 U.S. 225 (1969).

64. FRANK T. READ \& LUCY S. MCGOUGH, LET THEM BE JUdGED 476 (1978).

65. See id. at 472-522; WILKINSON, supra note 36, at 108-27.

66. See KulL, supra note 22 , at 179. (asserting that "[i]n [Jefferson County] ... 
school districts to actively integrate schools and to ensure that blacks and whites attend school together, Green gave the force of law to the Brown Court's vision. Freedom of choice and the dismantling of the overt props used to support racial separation had not worked. It had not produced a society in which blacks and whites considered each other equals, or even attended school together, in the areas where segregation had been carried out by force of law only a few years earlier. Because the entrenchment of segregation demanded more forceful action than the Court had originally thought, the decision in Green required courts to use more intrusive remedies to enact true desegregation. Although the school policies had been facially race-neutral, the freedom to choose which school to attend was so corrupted by the previous segregative regime that neither blacks nor whites could be expected to integrate their schools on their own accord witlout prodding from the courts. ${ }^{67}$ The constitutional violation on which Brown was based-the injuries caused by the separation of black students from whites-still existed, and the Court's decision in Green was necessary to remedy the violation.

\section{Interpreting Brown: It's All in the Injury-Or is It?}

The Court in Brown successfully identified an injury-separation of blacks from whites-that required more of a remedy than the simple elimination of facial discrimination. In most situations, Green's affirmative duty represented the beginning of the end of dual school systems in previously legally segregated areas. As time has passed from the point when blacks were officially considered unequal to whites, however, articulating the constitutional injury in terms of separation from whites may have becoine anachronistic. This outcome was not addressed in Brown. To the Court in tliat decision, racial separation authorized by law represented an injury, regardless of the circumstances.

Judge Wisdom rewrote the Supreme Court's 1955 desegregation mandate to make it require that black and white pupils attend school together").

67. The Court's opinion in Green represented its tacit realization that facially neutral policies would not succeed in effecting integration. The inertia, or hostility, or whatever was keeping black and white students from going to school together, was treated by the Court as just another facet of the entrenchment of enforced segregation that needed to be affirmatively ameliorated. See Green v. County Sch. Bd., 391 U.S. 430, 437-38 (1968). 
Two decisions rendered before the rejection of the "separate but equal" doctrine in Brown explain how the Supreme Court came to believe that equal educational opportunity ${ }^{68}$ meant that black students should study alongside whites. In Sweatt v. Paint$e r,{ }^{69}$ the Court rejected as unequal a law school established for blacks by the state of Texas. Rather than open the University of Texas Law School to black students, the state had established a law school at the Texas State University for Negroes. ${ }^{70}$ Although the Court found that there was not substantial equality "[in] terms of number of the faculty, . . . size of the student body, scope of the library, [and] ... law review and similar activities,"71 what was more important to the Court was that "the University of Texas Law School possesses to a far greater degree those qualities which are incapable of objective measurement but which make for greatness in a law school." 72 Among the qualities enumerated in the opinion were the "position and influence of the alumni" and "traditions and prestige." 73 Under that standard, for law schools at least, segregated institutions could not possibly be equal.

The law school to which Texas is willing to admit petitioner excludes from its student body members of the racial groups which number $85 \%$ of the population of the State and include most of the lawyers, witnesses, jurors, judges and other officials with whom petitioner will inevitably be dealing when he becomes a member of the Texas Bar. With such a substantial and significant segment of society excluded, we cannot conclude that the education offered petitioner is substantially equal to that which

68. In San Antonio Indep. Sch. Dist. v. Rodriguez, 411 U.S. 1 (1973), the Supreme Court rejected a claim that students have a right to equal funding for schools under the aegis of the Equal Protection Clause of the Fourteenth Amendment. By refusing to declare that relying on property taxes to fund local school districts denied the students in poorer districts an "equal educational opportunity," the Court limited the definition of that phrase. See id. at 40-45. In remedying prior racial discrimination in education, however, the Court has sought to provide educational opportunities that are equal across racial lines. It is this latter understanding of the phrase "equal educational opportunity" that this Note addresses.

69. 339 U.S. 629 (1950).

70. Id. at 633. Texas was required either to provide blacks a separate institution providing the professional training or to offer them admission to the professional schools for whites. See also Missouri ex rel. Gaines v. Canada, 305 U.S. 337 (1938).

71. Sweatt, 339 U.S. at 633-34.

72. Id. at 634 .

73. Id. 
he would receive if admitted to the University of Texas Law School. ${ }^{74}$

Following this logic, any person destined to deal with the public at large could not have been treated equally while simultaneously having been excluded from such a substantial part of the population.

On the same day, the Supreme Court announced its decision in McLaurin v. Oklahoma State Regents. ${ }^{75}$ In that case, a black man with a master's degree applied for admission to a doctoral program at the University of Oklahoma. ${ }^{76} \mathrm{~A}$ district court forced the school to admit him." Because a state statute required that all instruction at public imstitutions be done in a segregated atmosphere, the university segregated McLaurin from the white students. As a consequence, he sat in designated desks im classrooms and in the library apart from the other students and could not eat in the cafeteria at the same time as the other students. ${ }^{78}$ In declaring that type of disparate treatment unconstitutional, the Court held that "[s]uch restrictions [on interaction with other students] impair and inhibit his ability to study, to engage in discussions and exchange views with other students, and, in general, to learn his profession."79 Absent such restrictions, presumably, the student would profit from the resulting interaction with the other students; the restrictions therefore represented a denial of equal protection.

In McLaurin, as in Brown, all the "material" factors-the total monetary value of the resources allocated-were assumed to be equal. The only reason to invalidate the policies in the name of equal protection was the enforced separation of black and white students. Because McLaurin was subject to restrictions in his interactions with white students, the system was struck down. Similarly, the segregation in Brown was unconstitutional because there were injuries resulting from the separation of black students from white students. ${ }^{80}$ As Robert L. Carter, General Counsel for the NAACP

74. Id.

75. 339 U.S. 637 (1950).

76. Id. at 638.

77. Id. at 639. According to the doctrine developed in Missouri ex rel. Gaines v. Canada, 305 U.S. 337 (1938), and Sipuel v. Board of Regents, 332 U.S. 631 (1948), Oklahoma had to provide the same type of graduate education to McLaurin as it did to its white students.

78. McLaurin, 339 U.S. at 640 .

79. Id. at 641 .

80. Robert L. Carter, Equal Educational Opportunity for Negroes-Abstraction or 
from 1956-1968, insisted, "[W]hether the state commands the segregation, builds upon it, or merely accepts it, the same invalid classification, the injury, or inequality takes place. The fact that law ordains the segregation merely aggravates its illegality."11

Enforced segregation, then, was the fence that had to be removed for this reorganization to occur. David Kirp writes,

The remedy for the sins Brown identified followed directly from the recital of the wrong: abolish state-imposed racial separation. Once racial barriers were lifted, it was supposed, there would exist neither white schools nor black schools, but "just schools." When the dual school system was dismantled, the constitutional rights of blacks would be secured; so too would their opportunity for social and economic equality. Blacks, like whites, would then be free to succeed or fail on the basis of merit, not caste. ${ }^{82}$

Once the legal barriers were broken down, anything less than color-blind assimilation through integration would not meet the constitutional standard. This vision depended on blacks receiving a substantive benefit from the efforts to eliminate the separation and remedy that constitutional injury.

This vision, however, does not correspond with any concept of equal protection if the stigma of separation, the injury that integration is designed to prevent, is eliminated. The integrative ideal completely denies blacks any opportunity to have "equal" schools that are "separate," even if blacks would prefer that solution and even if it produced better educational outcomes for black students. ${ }^{83}$ As desegregation scholar J. Harvie Wilkinson notes,

[T] he Court in Brown dealt blacks an unwitting slight. Even if school facilities were equal, Brown had held, blacks were still

Reality, in WiTh All Deliberate Speed 56, 61 (John H. McCord ed., 1969).

81. Id. Carter points to the Brown opinion to support his view: "Segregation of white and colored children in public schools has a detrimental effect upon the colored children. The impact is greater when it has the sanction of the law." Id. at $61 \mathrm{n.21}$ (quoting Brown v. Board of Educ., 347 U.S. 483, 494 (1954) (emphasis added)).

82. DAVID L. KIRP, JUST SCHOOLS: THE IDEA OF RACIAL EQUALITY IN AMERICAN EDUCATION 6 (1982) (footnote omitted).

83. See DERRICK Bell, AND WE ARE NOT SAVEd 104 (1987) (describing the hypothetical W.E.B. Du Bois School, "an all-black, outstanding educational facility with a national reputation," where black parents appeal a desegregation plan that would require the integration of their school). It is not too difficult to imagine predominantly black schools that educate black students better than predominantly white schools, if, for example, black students are better able to adapt to the surrounding social environment. See, e.g., JACQUeline Fleming, BLACKS IN COLLEGE 150-53 (1984). 
being deprived. Separate, Brown emphasized, was inherently unequal. If this holding on the surface buoyed black morale, its undercurrents, in time, just as certainly depressed it. For Brown implied first, that black schools, whatever their physical endowments, could not equal white ones; second, that integration was a matter of a white benefactor and a black beneficiary .... Progress was measured ... by how many blacks entered the promised land of white classrooms. ${ }^{84}$

Success in reinedying the constitutional injury was not measured in terms of black students' educational gains; under Brown, it could not be. Evidence of integration substituted for any evidence that black students were profiting from the increased educational opportunities that were supposed to flow from the unitary school system. At the saine time, some blacks questioned the actual benefit of integration, even as schools met the requirements of Brown. ${ }^{85}$

Further dissatisfaction with the mixing of black and white students as the reinedy for past discrimination has led some black scholars to reconsider whether separate but equal was necessarily a worse policy than imtegration. Derrick Bell has suggested that the courts be more flexible in determining how to establish equal educational opportunity. "The principles of Plessy v. Ferguson as well as Brown v. Board of Education can be used effectively. No approach should be discarded, and few should be universally embraced." ${ }^{86}$ In other words, perhaps the separate but equal stan-

84. WILKINSON, supra note 36 , at 46 (citation omitted); see also David Hall \& George Henderson, Thirty Years After Brown: Looking Ahead, 24 WASHBURN L.J. 227, 238 (1985) ("[T]о hold that 'separate educational facilities for Blacks are inherently unequal' is to proffer the assumption that Blacks are inherently inferior to Whites. This assumption has been a cornerstone of the American legal system since its inception. Instead of destroying this assumption, Brown reinforced it-albeit in a more subtle form.") (citation omitted).

85. For the separatists that marked the fringe of the Black Power movement in the 1960 s, the integration necessary to comply with Brown represented the death of black culture. Integration meant "full assimilation . . . . [E]ven if [integration] should somehow be achieved, .... its price might be the total absorption and disappearance of the [black] race-a sort of painless genocide." Robert S. Browne, The Case for Two Americas-One Black, One White, N.Y. TIMES, Aug. 11, 1968, \& 6 (Magazine), at 12, 51.

86. Derrick A. Bell, Jr., Waiting on the Promise of Brown, 39 LAW \& CONTEMP. PROBS., Spring 1975, at 341, 373; see also PREER, supra note 6, at 189-222 (chronicling an uneasiness on the part of many with closing predominantly black colleges for the sake of integrating post-secondary education). Compare Derrick A. Bell, Jr., Serving Two Masters: Integration Ideals and Client Interests in School Desegregation Litigation, 85 YALE 
dard accepted in Plessy could be viably used in the education of black children. Because attending school with white students has not appeared unconditionally to raise blacks' educational achievement, ${ }^{87}$ Brown's equation of integration with equal educational opportunity could, and should, be questioned. The Court's holding in Brown was predicated on a rather wooden definition of the injury caused by segregation: the stigma related to segregation because of perceived inferiority. If that stigma is not present and if acts of voluntary separation appear to improve blacks' educational achievement, Brown's declaration that separate is inherently unequal lacks a constitutional foundation.

\section{UNITED STATES V. FORDICE AND ITS APPLICATION OF GREEN TO INSTITUTIONS OF HIGHER LEARNING}

As courts imposed mandatory integration remedies on elementary and secondary schools, the question remained whether Green's broad mandate would affect higher education. Certainly, the same reminders of the legally segregated past existed; virtually all public universities in the South in the late 1960s were overwhelmingly one-race schools. ${ }^{88}$ There are, however, some differences between grade schools and colleges that could affect the analysis. Colleges are not fungible; unlike lower schools, states ordinarily offer a diverse choice of higher education institutions. Also, students choose which college to attend, whereas children generally are assigned to an elementary or secondary school. Finally, because of the existence of student choice at a college level, the primary remedy in local school district desegregation cases-student assignment-is not available. For many years after the broad remedial mandate of Green became mandatory for primary and secondary schools, states had no definitive answer concerning their duties in desegregating higher education institutions.

In the final days of its 1992 Term, the Supreme Court announced its decision in United States $v$. Fordice, ${ }^{89}$ a case that de-

L.J. 470, 516 (1976) ("The time has come for civil rights lawyers to end their singleminded commitment to racial balance, a goal which . . . is . . . all too often educationally impotent.") with Nathaniel R. Jones, Correspondence, 86 YALE L.J. 378, 379 (1976) ("Segregation is itself the deepest educational harm.").

87. See infra notes $173-75$ and accompanying text.

88. See David E. Kendall, Note, The Affirmative Duty to Integrate in Higher Education, 79 YALE L.J. 666, 673-75 (1970).

89. 112 S. Ct. 2727 (1992). 
termined that the Mississippi state university system discriminated in its provision of facilities to blacks and held that Mississippi had to take affirmative steps to integrate its colleges. The system has been comprised since before the Brown decision of five historically white and three historically black colleges. ${ }^{90}$ The Court held that, although colleges are distinguishable from primary and secondary schools, states have an affirmative duty to eliminate the vestiges of the prior dual university system. "If policies traceable to the de jure system are still in force and have discriminatory effects, those policies too inust be refonned to the extent practicable and consistent with sound educational practices." 11

\section{A. Higher Education Desegregation Jurisprudence Leading to Fordice}

Before the Court's decision in Fordice, the law regarding a state's duty to take positive steps to integrate its colleges and universities had been far froin clear. The Supreine Court's only two forays into this area had been entirely contradictory. In 1969, in Alabama State Teachers Association v. Alabama Public School $\&$ College Authority, ${ }^{92}$ the Court affirmed a district court decision affecting the construction of a branch of a historically white university in a city where a predominantly black college already existed. The construction of the branch would discourage whites from attending the historically black college in the area. The district court noted that "no court in dealing with desegregation of institutions in the higher education area has gone farther than ordering nondiscriminatory admissions." ${ }^{.93}$ The court noted that, although the "State is under an affirmative duty to dismantle the dual systein, ... [w]e [do not] agree that the scope of the duty should be extended as far in higher education as it has been in the elementary and secondary public schools area." ${ }^{14}$

The rationale for that assertion lay in the distinctions between the two levels of education. Schooling for elementary and high school children is free and required by law. ${ }^{95}$ Students are ordi-
90. Id. at 2732 .
91. Id. at 2736 .
92. 393 U.S. 400 (1969) (per curiam).
93. Alabama State Teachers Ass'n v. Alabama Pub. Sch. \& College Auth., 289 F. Supp. 784, 787 (M.D. Ala. 1968), aff'd, 393 U.S. 400 (1969) (per curiam).

94. Id.

95. See Adam M. Greenfield, Note, Annie Get Your Gun 'Cause Help Ain't Comin': 
narily assigned to elementary and high schools because "in principle at least, one school for a given grade level is substantially similar to another." nor compulsory." Moreover, colleges are far from being "fungible;", in deciding where to attend college, students "face the full range of diversity in goals, facilities, equipment, course offerings, teacher training and salaries, and hiving arrangements." 99

Thus, as long as the state and the individual colleges and universities acted in good faith to eliminate intentional racial discrimination from their administration, their constitutional duties were satisfied. Although the district court acknowledged the Suprenie Court's decision in Green as imposing a duty to eliminate the vestiges of prior segregation "root and branch,"100 it did not interpret that decision to apply to segregation at the college level. "Freedom to choose where one will attend college, unlike choosing one's elementary or secondary public school, has a long tradition and helps to perform an important function, viz., fitting the right school to the right student."101

On the other hand, in 1971, the Court affirmed, without opinion, a district court opinion from Virginia that struck down a sinilar plan to upgrade a two-year predominantly white institution into a four-year college located near a historically black college. ${ }^{102}$ There, the district court held,

In Green, though the Court was dealing with discrimination affecting public school pupils, it defined a constitutional duty owed as well to college students. The means of eliminating discrimination in public schools necessarily differ from its elimination in colleges, but the state's duty is as exacting. Thus, to paraphrase Green, a state is obliged to convert its white colleges and black colleges to just colleges. ${ }^{103}$

The Need for Constitutional Protection from Peer Abuse in Public Schools, 43 DUKE L.J. 588, 588 n.1 (1993).

96. Alabama State Teachers Ass'n, 289 F. Supp. at 788.

97. Id.

98. See United States v. Fordice, 112 S. Ct. 2727, 2736 (1992).

99. Alabama State Teachers Ass'n, 289 F. Supp. at 788.

100. See Green v. County Sch. Bd., 391 U.S. 430.439 (1968).

101. Alabama State Teachers Ass'n, 289 F. Supp. at 790.

102. Board of Visitors v. Norris, 404 U.S. 907 (1971).

103. Norris v. State Council of Higher Educ., 327 F. Supp. 1368, 1373 (E.D. Va.) (three-judge court) (citations omitted), affd, 404 U.S. 907 (1971). 
Because the court found that Green apphed to colleges in their attempt to desegregate, "one agency of the state ... cannot innpede another agency of the state ... in its efforts to fully integrate its student body." ${ }^{104}$ As a result, the white college was enjoined from establishing a branch that would directly compete with the black college for entering students. For the Norris court, a state's elnnination of facial discrimination was insufficient to ineet its constitutional duties under Brown; instead, states must take affirmative steps to eliminate the vestiges of their previously $d e$ jure segregated college systems.

Despite this rift in its own opinions, the Supreme Court refused to consider more substantially the specific issue of desegregation of colleges and universities. The Court did make an innortant distinction, however, in determining whether a state had an affirmative duty to integrate in a related context. In Bazemore $v$. Friday, ${ }^{105}$ the Court determined that providing free choice satisfied a state's duty with regard to educational extracurricular activities. Prior to $1965,4-\mathrm{H}$ and Hoinemaker Clubs, run by North Carolina's Agricultural Extension Service through the public schools, were entirely segregated. ${ }^{106}$ In 1964, the Extension Service rewrote its policy, opening all such clubs "to any otherwise eligible person regardless of race." ${ }^{107}$ Although some clubs reinained single-race, there was no violation of the Fourteenth Amendinent because "one's choice of a Club is entirely voluntary." 108 Justice White, in a concurrence joined by four other Justices, held that to meet its constitutional duty the state needed only to establish a nondiscriminatory adnnissions systein. As such, the Court affirmed the district court's factual conclusion that "any racial imbalance existing in any of the clubs was the result of wholly voluntary and unfettered choice of private individuals." 109

The Court distinguished Green's holding that neutral voluntary choice prograins did not necessarily fulfill the constitutional duty to desegregate in a lower school context by declaring that Green "has no apphication to the voluntary associations supported by the

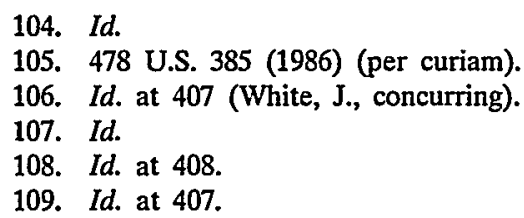


Extension Service."110 The distinction was that although children are assigned to a school they must attend, they may choose the club to which they want to belong, if they want to belong to one at all.

While schoolchildren must go to school, there is no compulsion to join 4-H or Homemaker Clubs, and while school boards customarily have the power to create school attendance areas and otherwise designate the school that particular students may attend, there is no statutory or regulatory authority to deny a young person the right to join any Club he or she wishes to join .... [H]owever sound Green may have been in the context of the public schools, it has no application to this wholly different milieu. ${ }^{111}$

When personal choice is involved in determining whether to participate and with whom to associate, it appeared, after Bazemore, that all a state was required to do was establish a neutral policy. Any racial identifiability that occurred afterward would be purely the result of that choice, not the vestige of prior compelled segregation. Green's requirement of affirmative steps to imtegrate could not extend that far because free choice had caused whatever racial identifiability that existed.

\section{B. Desegregating Mississippi's Universities: Fordice Extends Green}

From 1844, when Mississippi opened its first public university, until 1954, the state had forthrightly maintained its colleges and universities on a strictly segregated basis. ${ }^{112}$ Even after Brown, the university system continued to segregate students; the first black student to enter the University of Mississippi, James Meredith, did so only by force of a court order. ${ }^{113}$ By 1970 , all eight of Mississippi's institutions of higher learning (five historically

110. Id. at 408 .

111. Id.

112. Ayers v. Allain, 674 F. Supp. 1523, 1526-28 (N.D. Miss. 1987), rev'd, 893 F.2d 732 (5th Cir.), rev'd, 914 F.2d 676 (5th Cir. 1990) (en banc), vacated sub nom. United States v. Fordice, 112 S. Ct. 2727 (1992). The University of Mississippi was founded in 1844, id. at 1526; Alcorn State University, "the oldest land grant college for blacks in the United States," traces its beginnings to 1830 , when it was established to educate whites. Id. at 1527.

113. Id. at 1528. See Meredith v. Fair, 306 F.2d 374 (5th Cir.), cert. denied, 371 U.S. 828, enforced, 313 F.2d 532 (5th Cir. 1962) (per curiam). 
white, three historically black) had admitted a student of the other race. ${ }^{114}$

In 1969, the Department of Health, Education and Welfare (HEW) attempted to enforce Title VI of the Civil Rights Act of 1964 by askmg the Mississippi state authorities to devise a plan to desegregate their higher education facilities. ${ }^{115}$ In 1973, a group of plaintiffs from several states successfully sued HEW to force the agency to apply Title VI to states that had yet to formulate a desegregation plan; Mississippi was one of ten states named. ${ }^{116}$ Because of HEW pressure, Mississippi's Board of Trustees of State Institutions of Higher Learning finally adopted a plan in 1975 (which ultimately did not obtain HEW's approval) calling for numerical goals for other-race students at the schools, hiring otherrace faculty members, and special recruitment plans to achieve those goals. ${ }^{117}$ The state legislature, however, refused to provide the necessary funding for the plan until 1978, and then at far less than half the amount requested by the Board. ${ }^{118}$

A group of black Mississippi citizens filed suit in 1975, alleging that Mississippi was violating their rights under the Constitution and Title VI. Several months later, the United States intervened, joming their Title VI claim. ${ }^{119}$ In twelve years of negotiation, several compromises were reached. In 1976, the state revised the admissions requirements for all the schools, establishing minimum American College Test (ACT) scores that would guarantee

114. Ayers, $674 \mathrm{~F}$. Supp. at 1529. The five historically white institutions are the University of Mississippi, Mississippi State University, University of Southern Mississippi, Mississippi University for Women, and Delta State University. The three black institutions are Alcorn State University, Jackson State University, and Mississippi Valley State University. Id.

115. Adams v. Richardson, 356 F. Supp. 92, 94 (D.D.C.), modified and affd, 480 F.2d 1159 (D.C. Cir. 1973).

Title VI of the 1964 Act reads, "No person in the United States shall, on the ground of race, color, or national origin, be excluded from participation in, be denied the benefits of, or be subjected to discrimination under any program or activity receiving Federal financial assistance." 42 U.S.C. $\$ 2000$ d (1988). Because most universities receive federal appropriations in the form of research grants and financial aid for students, they are subject to Title VI. The penalty for noncompliance is the withholding of those federal funds. See id. § $2000 \mathrm{~d}-1$.

116. Adams, 356 F. Supp. at 92-102.

117. United States v. Fordice, 112 S. Ct. 2727, 2732-33 (1992). At this time, the universities were overwhelmingly single-race. See infra note 128.

118. Id. at 2733 .

119. Id. 
admission to each institution. ${ }^{120}$ The three principal white universities required a score of 15 , and the minimum score to guarantee admission at any historically black university was 9. At the time, the average score for whites in the state was 18; the average score for blacks was $7 .{ }^{121}$ The required scores have shifted through the years; when the Supreme Court considered Fordice, a score of 15 guaranteed admittance to the predominantly white schools, whereas a 13 was necessary to attend the predominantly black schools. ${ }^{122}$

Also as part of its plan of compliance, the Board of Trustees attempted in 1981 to define the academic inission that each institution should achieve. The three previous flagship colleges, ${ }^{123}$ all historically white, were nained the "comprehensive" institutions. These universities were to receive the most resources and offer the most programs. Jackson State would become an "urban university" and "[would be] assigned a more limited research and degree mission, with both functions geared toward its urban setting."124 The remaining four institutions, two historically black and two historically white, were designated "regional" institutions, with a primary mission of teaching undergraduates. ${ }^{125}$

Despite these niarginal miprovennents in the educational opportunities afforded to black students, the class of black plaintiffs found then unacceptable, and the case proceeded to trial. ${ }^{126}$ The district court found that the racial identifiability of each of the colleges had not diminished substantially since 1975 , in part be-

120. Ayers v. Allain, 674 F. Supp. 1523, 1532 (N.D. Miss. 1987), rev'd 893 F.2d 732 (5th Cir.), rev'd, 914 F.2d 676 (5th Cir. 1990) (en banc), vacated sub nom. United States v. Fordice, 112 S. Ct. 2727 (1992).

121. Id. at 1532. The purpose of that policy, the district court found, was to deny black students the opportunity to attend those institutions. By establishing standards beyond the reach of most black students, who had generally poorer training in black secondary schools, the state was attempting to create facially race-neutral criteria that would result in almost entirely white institutions. Id. at 1531.

122. Fordice, $112 \mathrm{~S}$. Ct. at 2739. The sole exception was the Mississippi University for Women, which required a score of 18 . The state justified these standards on the ground that they reflected an attempt to admit students who were prepared for the academic program at the university. Id.

123. The University of Mississippi, Mississippi State University, and the University of Southern Mississippi were first designated as "flagship" schools, then as "comprehensive" institutions. Ayers, 674 F. Supp. at 1539.

124. Fordice, 112 S. Ct. at 2733.

125. Id. at 2742.

126. See Ayers, 674 F. Supp. at 1526. 
cause of the contmuing duplication of programs between historically black universities and historically white institutions. The Supreme Court concurred, finding that " 34.6 percent of the 29 undergraduate programs at historically black institutions are 'unnecessarily duplicated' by the historically white universities, and . . 990 percent of the graduate programs at the historically black institutions are unnecessarily duplicated at the historically white institutions." 127 Despite this duplication, at no time did the state make an effort to merge any of the existing universities; it maintained all of them despite the lasting racial identifiability. ${ }^{128}$

Relying on Alabama State Teachers Association and Bazemore, the district court concluded that "the scope of the affirmative duty to disestablish a former de jure segregated system of education is to be defined in accordance with the degree of choice individuals enjoy as to whether they wish to attend college at all and, if so, which one." 129 Therefore, "emphasis should ... be placed on current state higher education policies and practices in order to insure that such policies and practices are racially neutral, developed and implemented in good faith, and do not substantially contribute to the continued racial identifiability of individual insti-

127. Id. at 1541 .

128. Fordice, $112 \mathrm{~S}$. Ct. at 2742 . The enrollment patterns demonstrate the identifiability of each of the campuses. The tables list the percentage of other-race students (i.e., students that are not of the race that historically attended the school) at each school.

$\begin{array}{lcrr}\text { Historically White Institutions } & 1973-1974 & 1980-1981 & 1985-1986 \\ & & & \\ \text { Delta State Univ. } & 14.3 \% & 17.1 \% & 17.6 \% \\ \text { Mississippi State Univ. } & 5.6 \% & 11.2 \% & 11.0 \% \\ \text { Mississippi Univ. for Women } & 9.9 \% & 19.3 \% & 18.0 \% \\ \text { Univ. of Mississippi } & 3.5 \% & 7.0 \% & 5.9 \% \\ \text { Univ. of Southern Mississippi } & 4.5 \% & 11.3 \% & 1424 \% \\ & & & \\ \text { Historically Black Institutions } & 1973-1974 & 1980-1981 & 1985-1986 \\ & & & \\ \text { Alcorn State Univ. } & 0.3 \% & 3.1 \% & 4.4 \% \\ \text { Jackson State Univ. } & 0.4 \% & 4.8 \% & 8.1 \% \\ \text { Mississippi Valley State Univ. } & 0.3 \% & 0.2 \% & 0.7 \%\end{array}$

"[In] 1986, over $99 \%$ of the white students . . . were enrolled in historically white institutions and over $71 \%$ of the black students ... were enrolled in historically black institutions." Ayers v. Allain, 893 F.2d 732, 734-35 (5th Cir.), rev'd, 914 F.2d 676 (5th Cir. 1990) (en banc), vacated sub nom. United States v. Fordice, 112 S. Ct. 2727 (1992).

129. Ayers, 674 F. Supp. at 1553. 
tutions." 130 With this standard, the district court found that Mississippi was fulfiling its duties under both Title VI and the Constitution. ${ }^{131}$

A panel of the Fifth Circuit reversed the district court, holding that Mississippi had an affirmative duty to disestablish the de jure systein of segregation by vigilantly attacking its vestiges, according to the interpretation of the principles of Brown $I$ and Brown II announced in Green. ${ }^{132}$ That decision, however, was quickly overruled by the Fifth Circuit en banc. ${ }^{133}$ Finding the disparities between the predominantly white and predominantly black institutions "very much reminiscent of the prior system," the court nevertheless held that the plaintiffs were not "denied equal educational opportunity or equal protection of law. [Mississippi has] adopted good-faith, race-neutral policies and procedures and ha[s] fulfilled or exceeded [its] duty to open Mississippi universities to all citizens regardless of race."134 Relying on Bazemore and Alabama State Teachers Association, the Fifth Circuit consequently affirmed the district court's judgment.

The Supreme Court thus had two appellate opinions from the Fifth Circuit, each advocating one of the two disparate means of analysis that the Court had summarily affirmed in Alabama State Teachers Association and Norris. With the issue thus framed, the Court held that Mississippi, having previously been segregated by law, "[would] not discharge its constitutional obligations until it eradicate[d] policies and practices traceable to its prior de jure dual system that continue[d] to foster segregation."135 It is not necessary to eradiate racial identifiability, but the state may not contribute to it by maintaining policies that continue to restrict students' choices of where to attend college.

The Court acknowledged the distinctions between discrimination in elementary and secondary education and in higher education.

Unlike attendance at the lower level schools, a student's decision to seek higher education has been a matter of choice. The State

130. Id. at 1554 .

131. Id. at 1564 .

132. Ayers, 893 F.2d at 756 .

133. Ayers, 914 F.2d at 676.

134. Id. at 692.

135. United States v. Fordice, 112 S. Ct. 2727, 2735 (1992). 
historically has not assigned university students to a particular institution. Moreover, like public universities throughout the country, Mississippi's institutions of higher learning are not fungible-they have been designated to perform certain missions. Students who quahify for adinission enjoy a range of choices of which institution to attend. ${ }^{136}$

Nevertheless, the adoption of facially race-neutral policies alone did not terminate the state's duty to eradicate the dual system, even at the level of higher education. Factors that enter into a prospective student's choice of where to matriculate may be determined in part by policies that are directly traceable to the prior de jure system. "If policies traceable to the de jure systein are still in force and liave discriminatory effects, [for a state to fulfill its constitutional duty,] those policies too must be reformed to the extent practicable and consistent with sound educational practices."137 The district court had placed the burden on the plaintiffs to demonstrate that sucl effects were in fact contributing to racial identifiability. The Court made clear that "Brown and its progeny ... established that the burden of proof falls on the State, and not the aggrieved plaintiffs, to estabhish that it has dismantled its prior de jure segregated system." 138

In deciding that the enactment of facially nondiscriminatory admissions policies did not fulfill a state's duty to dismantle its former dual system, the Fordice Court drew an analogy to the freedoin-of-choice plans in primary and secondary schools that were rejected in Green. Sucli an analogy is tantamount to ordering the integration of university systens and the elimination of all racial identifiability of state colleges. As Justice Scalia noted in his separate opinion, the imposition of a burden on the state to prove that its continuing policies do not "substantially restrict a person's clioice of whicl1 institution to enter"139 miperils "virtually any practice or program plaintiffs decide to challenge-just as Green has-so long as racial mibalance remains."140 More miportantly,

136. Id. at 2736.

137. Id. (citing Freeman v. Pitts, 112 S. Ct. 1430, 1446 (1992)).

138. Id. at 2741 (citing Brown v. Board of Educ., 349 U.S. 294, 300 (1955)).

139. Fordice, 112 S. Ct. at 2747 (Scalia, J., concurring in the judgment and dissenting in part) (citing id. at 2738).

140. Id. at 2748 (alteration omitted). As Justice Scalia noted, "[T]oday's opinion requires state university administrators to prove that racially identifiable schools are not the consequence of any practice or practices ... held over from the prior de jure regime." 
Justice Scalia believed the only way to disprove any continuing segregative effect in the schools "is to eliminate extant segregation, i.e., to assure racial proportionality in the schools." 141 In his judgment, the unfettered clioice of higher education institutions that may be racially identifiable does not implicate the same stigmatic effect as in the lower school environment, where students are generally assigned to a particular scliool. ${ }^{142}$

By means of illustration, the Court demonstrated low, under its new standard, several of the state's policies represented "constitutionally suspect" surviving aspects of Mississippi's prior dual system. ${ }^{143}$ Even if these policies are facially neutral, they may substantially restrict a person's choice of which institution to enter and therefore contribute to the racial identifiability of the university system. ${ }^{144}$

1. Admissions Requirements. The admissions requirements, for exainple, based on ACT scores, had their genesis in intentional acts by the state to keep blacks from attending historically white sclools. ${ }^{145}$ The Board of Trustees altered those standards in the mid-1970s, asserting a race-neutral justification of preparedness and distinguishing between the comprelensive umiversities and the regional colleges, rather than between the historically white and black institutions. ${ }^{146}$ The Court believed that such a choice required additional justification "in terms of sound educational policy" to demonstrate that it was not a mere pretext for maintaining the racial identifiability of the scliools. ${ }^{147}$

\footnotetext{
Id.

141. Id.

142. Id. at 2749; see Brief for Respondent at 37-38, United States v. Mabus, $112 \mathrm{~S}$. Ct. 2727 (1992) (Nos. 90-1205 and 90-6588) (arguing that desegregation of state universities "do[es] not present the same kinds of cognizable difficulties inhering in elimination of racial classifications in schools, at which attendance is compulsory, the adequacy of teachers and facilities crucial, and questions of geographic assignment often of major sig. nificance") (quoting Watson v. City of Memphis, 373 U.S. 526, 532 (1963) (emphasis added)); id. at 41 ("Our analysis in Bazemore ... reflected our unwillingness to conclude, outside the context of school assignment, that the continuing effects of prior discrimination can be equated with state maintenance of a discriminatory system.") (quoting City of Richmond v. J.A. Croson Co., 488 U.S. 469, 525 (1989) (Scalia, J., concurring) (emphasis added)).
}

143. Fordice, 112 S. Ct. at 2738.

144. Id.

145. Id.

146. Id. at 2739.

147. Id. at 2740 . The Court also questioned the state's failure to consider high school 
2. Duplication of Programs. Similarly, the duplication of programs between historically black and historically white universities required further justification. On its face, such duplication appeared to be a vestige of the former dual systen1. Because there was substantial duphcation of programs between the white and black institutions, there was less incentive for students to attend schools where they would be in the racial minority. Most programs were available at both a white and a black school, and neither whites nor blacks were encouraged to attend a particular school for a unique course of study. As Justice White wrote for the Court, "It can hardly be denied that such duplication was part and parcel of the prior dual system of higher education-the whole notion of 'separate but equal' required duplicative programs in two sets of schools ...."148

Especially given the continued existence of all eight institutions, the racial identifiability of each school needed to be justified on the basis of sound, race-neutral educational goals.

That an institution is predominantly white or black does not in itself make out a constitutional violation. But surely the State may not leave in place policies rooted in its prior officially-segregated system that serve to maintain the racial identifiability of its universities if those policies can practicably be eliminated without eroding sound educational policies. ${ }^{149}$

Barring a sufficient explanation of why state colleges were segregated that does not rely on the effects of prior segregative actions, Mississippi state officials bore the responsibility of taking action to reduce the racial identifiability of their college campuses. ${ }^{150}$

grade point averages as a factor in addition to ACT scores. The disparity between blacks' and whites' grade point averages was not nearly so great as the difference in ACT scores. Id. at 2740 n.10. The Board of Trustees stated that the reliance on standardized test scores reflected a concern about "grade inflation and the lack of comparability in grading practices and course offerings among the State's diverse high schools." Id.

148. Id. at 2741.

149. Id. at 2743 .

150. The Court noted that mergers of historically black and historically white institutions would have decreased the racial identifiability of the higher education system. "The District Court pointed especially to the fact[] that Delta State and Mississippi Valley are only 35 miles apart." Id. at 2742. 
3. Inequitable Distribution of Resources. The Court also found that Mississippi had contributed to the inferiority of its black schools by providing more resources and establishing more advanced programs at the predominantly white colleges. ${ }^{151}$ The University of Mississippi, Mississippi State University, and the University of Southern Mississippi were the most comprehensive universities in the system. ${ }^{152}$ The three exclusively black institutions, by contrast, were much more limited in their academic programs. ${ }^{153}$ Establishing advanced programs only at predominantly black colleges, for example, could have attracted white students, thus facilitating integration.

In conclusion, the Court declared that, because Mississippi historically impeded the students' choices of where to attend college, the state must take steps "to ensure that this choice now is truly free." 154 All policies and practices must be considered "in order to create an environment free of racial discrimination and to make aggrieved individuals whole."155 According to Justice White, the district court and the court of appeals disregarded an important distinction: in Bazemore, the Court accepted a raceneutral admissions policy as fulfilling the state's constitutional duty to desegregate only after finding that the state had not fostered segregation by mamtaining vestiges of de jure segregation. In Bazemore, the choice truly was free, not corrupted by remaining aspects of the prior system that caused students to remain separated. ${ }^{156}$ The Mississippi district court erred by not inquiring whether certain aspects of the formerly segregated regime continued to affect the system so as to maintain segregation on the basis of race. ${ }^{157}$

151. Id. at 2741 .

152. Id. at 2742 .

153. Id. The Court noted that "Alcorn State, for example, was designated to serve as 'an agricultural college for the education of Mississippi's black youth'" and that Mississippi Valley State and Jackson State were established to train teachers for the elementary and secondary black schools in the state. Id. at 2741 (quoting Ayers v. Allain, $674 \mathrm{~F}$. Supp. 1523, 1527-28 (N.D. Miss. 1987), rev'd, 893 F.2d 732 (5th Cir.), rev'd, 914 F.2d 676 (5th Cir. 1990) (en banc), vacated sub nom. United States v. Fordice, 112 S. Ct. 2727 (1992)).

154. Fordice, 112 S. Ct. at 2743.

155. Id. at 2743 (O'Connor, J., concurring).

156. Id. at 2737 (citing Bazemore v. Friday, 478 U.S. 385, 407 (1986)).

157. Policies that perpetuate segregative effects and that do not have a sound educational justification "run afoul of the Equal Protection Clause, even though the State has 
Although Justice Scalia declared that the injury that existed in Green could not possibly exist in the context of higher education, Justice White, for the Court, correctly pointed out that the existence of choice alone does not eliminate a state's duty to ensure that the choice is one free from the stigmatic effects stemming from the former de jure system. On the other hand, the Court did not allow for the possibility that choice may be free in fact even when certain vestiges of the former system, such as racially identifiable schools, still exist. That failure could unnecessarily deny black students educational opportunities they currently enjoy.

\section{GREEN REMEDIES IN THE HIGHER EDUCATION CONTEXT}

In his concurrence in Fordice, Justice Thomas hoped that the Court's focus on "sound educational practices"158 in remedying past discrimination would prevent the integration of black college campuses, because predominantly black universities have been among the most successful in educating black students. ${ }^{159}$ Such hopes are likely misplaced, however. The necessity of implementing policies in accordance with "sound educational practices" was acknowledged in elementary and secondary school cases under the Green standard, and it did not lead courts to consider whether predoininantly black schools were better situated to educate black students. ${ }^{160}$ It is more likely that Fordice will provoke states to

abolished the legal requirement that whites and blacks be educated separately and has established racially neutral policies not animated by a discriminatory purpose." Id. Justice Scalia, on the other hand, believed that Bazemore, with its emphasis on the freedom of association, should control this case. Id. at 2750 (Scalia, J., concurring in part and dissenting in part). There, the Court required evidence "of exclusion by race," Richmond v. J.A. Croson Co., 488 U.S. 469, 503 (1988) (commenting on Bazemore, 478 U.S. at 503), and did not require the defendants to prove that their actions did not contribute to racial identifiability. Undoubtedly, said Justice Scalia, the racial identifiability of university campuses is a vestige of the prior dual system. Fordice, $112 \mathrm{~S}$. Ct. at 2750 (Scalia, J., concurring in part and dissenting in part). Those vestiges, however, were equally apparent in Bazemore and were disregarded in consideration of the role played by individual choice. Justice Scalia argued that the Court should apply the same standard with regard to universities because of the similar role that personal choice plays in establishing the identifiability of a particular institution. Id. at 2751 (Scalia, J., concurring in part and dissenting in part).

158. Fordice, $112 \mathrm{~S}$. Ct. at 2736.

159. Id. at 2746 (Thomas, J., concurring).

160. See Swann v. Charlotte-Mecklenburg Bd. of Educ., 402 U.S. 1, 18 (1971). Although the soundness of the educational methods used in achieving desegregation is considered important by the Court, it would contravene Brown and its progeny to justify 
integrate all public universities, ending the long tradition of predominantly black colleges. Because this integration may be unnecessary for states to comply with their duty to provide equal protection of the law, this Note proposes a niore appropriate means to evaluate under the Equal Protection Clause the continued existence of racially identifiable colleges.

\section{A. Consequences of the Brown Mandate in the Context of Pre- dominantly Black Colleges}

In concluding the majority opinion in Fordice, Justice White made clear the Court's intention that Mississippi achieve real integration through adoption of policies that would reduce the racial identifiability of its colleges:

If we understand private petitioners to press us to order the upgrading of [Mississippi's black colleges] solely so that they may be publicly financed, exclusively black enclaves by private choice, we reject that request. The State provides these facilities for all its citizens and it has not met its burden under Brown to take affirmative steps to dismantle its prior de jure system when it perpetuates a separate, but "more equal" one. ${ }^{161}$

For the Court, then, the inequality, and therefore the constitutional violation, derive from the separation of students. When the black colleges are vestiges of the de jure system, as they virtually nust be when they were originally established as separate but equal institutions, their existence perpetuates the state's violation.

The Court disavowed such Green-type remedies that were as "radical" as student assignment in the context of higher education but did not discount racial identifiability as a characteristic and vestige of the de jure system. After affirming the need to evaluate remedies of constitutional violations for their educational soundness, Justice White wrote,

[T] he imappropriateness of remedies adopted in Green by no means suggests that the racial identifiability of the institutions in a university system is irrelevant to deciding whether a State such as Mississippi has satisfactorily dismantled its prior de jure dual system or that the State need not take additional steps to ameliorate such identifiability. ${ }^{162}$

continued racial separation on this basis.

161. Fordice, 112 S. Ct. at 2743.

162. Id. at $2736 \mathrm{n.4}$ (emphasis added). One remedy the Court considers inappropriate 
Racial identifiability remains an important consideration that a state must explain when challenged with allegations of continuing unconstitutional segregation. When it exists, the state has the difficult burden of proving that such segregation did not result from the vestiges of its policies. ${ }^{163}$

In response to the decision, the trustees of Mississippi's public university system proposed a plan that would close one of the three black colleges (Mississippi Valley State) and merge another (Alcorn State) with predominantly white Mississippi State. ${ }^{164}$ The plan's proponents hope it will imcrease minority enrollment on predominantly white campuses. ${ }^{165}$ Under the new plan, Jackson State would be upgraded to "comprehensive" status, involving the establishment of a number of new programs. The goal is to make the school more attractive to white students. ${ }^{166}$ The Fordice standard will likely cause other states to integrate publicly funded black colleges to avoid censure under Title VI. ${ }^{167}$ The plan has met serious opposition by black leaders, however, who want to maintaim black colleges primarily for black students, ${ }^{168}$ and by black students as well. ${ }^{169}$

is mandatory student assignment to a state's colleges and universities, id. at 2736, which would deny a student's choice of college based on its particular characteristics. See Ala'bama State Teachers Ass'n v. Alabama Pub. Sch. \& College Auth., 289 F. Supp. 784, 787-90 (M.D. Ala. 1968), aff', 393 U.S. 400 (1969) (per curiam); Kendall, supra note 88, at $680-82$.

163. See Fordice, 112 S. Ct. at 2748 (Scalia, J., concurring in part and dissenting in part) (noting that the Court's decision "places upon the state the ordinarily unsustainable burden of proving the negative proposition that it is not responsible for extant racial disparity in enrollment" in its universities).

164. Ronald Smothers, Blacks and Whites Condemn Plan to Integrate Mississippi Campuses, N.Y. TIMES, Oct. 23, 1992, at A1, A23.

165. Id. at A1.

166. Id. at A23. This goal is to be accomplished by the addition of graduate degree programs, an accredited business school, and social work and public administration programs.

167. See Keith L. Thomas, Public Black Colleges Have Proud History in the South, But Some May Face Trouble in Wake of Anti-Bias Lawsuit, ATLANTA J. \& CONST., Dec. 14,1992 , at A3.

168. The attorney who "won" in Fordice, Alvin Chambliss, declared Mississippi's plan "genocide." Ernie Freda, Washington in Brief, ATLANTA J. \& CONST., Apr. 8, 1993, at A4.

169. See Mary Jordan, In Mississippi, an Integration Uproar, WASH. POST, Nov. 17, 1992, at A1, A14; Mississippians Oppose Closing Black College, National Public Radio, Feb. 23, 1993, available in LEXIS, NEWS Library, NPR File. 
This focus on racial identifiability in trying to comply with Fordice is directly based on Brown's holding that the stigma attached to blacks by attending school apart from whites is an injury flowing from a violation of the Equal Protection Clause. This rationale presuines that such a stigina must exist whenever substantial separation of the races occurs in schools. The constitutional violation, however, should be based on a real injury, not the presumption of an injury whenever certain conditions suggest it. It is a real possibility that a stigma of inferiority does not exist with respect to predominantly black colleges. ${ }^{170}$ For example, a state defending its pohcies could point to the number of black students who choose to attend predominantly black colleges over institu-

170. There is a distinct difference between separation that derives from authoritarian imposition on a minority and the separation that occurs as a result of choice by members of a minority group.

Separatism imposed by empowered groups carries different symbolic and practical significance than separatism chosen by subordinate groups. Given this nation's historic traditions and cultural understandings, the exclusion of men from women's liberation groups or garden clubs no more conveys inferiority than the exclusion of whites from black associations or Protestants from Jewish social organizations. Nor does such exclusivity serve to perpetuate existing disparities in political and economic power. By contrast, the forms of institutional separatism chosen by dominant groups tend to reinforce their privileged positions and the stereotypes underlying them.

Deborah L. Rhode, Association and Assimilation, 81 Nw. U. L. REV. 106, 122 (1986).

Malcolm X spoke of school segregation similarly.

[A] segregated school system isn't necessarily the same situation that exists in an all-white neighborhood. A school system in an all-white neighborhood is not a segregated school system. The only time it's segregated is when it is in a community that is other than white, but at the same time is controlled by the whites. So my understanding of a segregated school system . . . is [one] that's controlled by people other than those that go there .... On the other hand, if we can get an all-black school, that we can control, staff it ourselves with the type of teachers that have our good at heart, with the type of books that have in them many of the missing ingredients that have produced this inferiority complex in our people, then we don't feel that an all-black school is necessarily a segregated school. It's only segregated when it's controlled by someone from outside .... I just can't see where if white people can go to a white classroom and there are no Negroes present and it doesn't affect the academic diet they're receiving, then I don't see where an all-black classroom can be affected by the absence of white children .... . So, what the integrationists, in my opinion, are saying, when they say that whites and blacks must go to school together, is that the whites are so much superior that just their presence in a black classroom balances it out. I can't go along with that.

MalColm X, BY ANY MEANS NecesSARY 16-17 (George Breitman ed., 1970). For Malcolm X, racial separation did not necessarily connote inferiority, but white control of predominantly black schools created a presumption of unequal conditions for black students. Colleges that remam predominantly black by choice, similarly, do not necessarily create the inferiority that de jure segregated institutions did before Brown. But see Sweatt v. Painter, 339 U.S. 629 (1950) (identifying the inferiority of a black law school segregated by statute); see supra text accompanying notes 69-74. 
tions that are predominantly white. ${ }^{171}$ Brown, Green, and Fordice do not speak to such a situation, and their holdings should be considered in hight of their presumptions and the applicability of those presuinptions to the condition of racial separation.

In particular, any evaluation of equality of education should consider how effectively predominantly black colleges educate their students relative to how well predominantly white colleges educate black students. ${ }^{172}$ Some sociological evidence suggests that black students are more likely to succeed at a predominantly black school than at a predominantly white mstitution. A 1984 study found that black students' intellectual gains are higher on mostlyblack campuses than at mostly-white schools. ${ }^{173} \mathrm{~A}$ more recent study noted the social and psychological effects of being a minority student at a predommantly white campus and described the ways in which social and extracurricular activities at black schools improve students' interpersonal relations, social networking, and academic success. ${ }^{174}$ Summarizing existing research, Professor Walter Allen noted, "Black students on Black campuses ... display more positive psychological adjustments, more sigmificant academic gams, and greater cultural awareness ... than Black

171. Seventeen percent of black college students attend publicly funded historically black colleges. In 1990 , more than $25 \%$ of black bachelor's degree recipients graduated from predominantly black colleges. Eric Harrison, For Blacks, a Crisis on the Campus, L.A. TrMES, Nov. 1, 1992, at A1, A16. Privately funded predominantly black institutions, such as Howard University, Morehouse College, and Spelman College, have retained their vitality as alternatives to integrated environments, even as elementary and secondary education has become more integrated. See, e.g., Jerry Thomas, Black Colleges' Cash Woes Keep Out Cream of Crop, CHI. TRIB., Nov. 9, 1992, at C1. There has been a renaissance in interest in many predominantly black colleges recently-enrollment at black schools rose $28 \%$ in the last six years, approximately twice the national average. See Tamara Henry, Returning to the Fold: Renewing the Investment in Black Schools, USA ToDAY, Dec. 2, 1993, at 1D, 2D.

172. One should evaluate black students' (rather than all students') education at predominantly white schools because desegregation is designed to remedy black students' constitutional injuries.

173. That study showed that

The results show that the patterns of intellectual development are consistently more positive for students in black schools. These students exhibit stronger personal attachments to faculty, enhanced involvement in the career process, greater satisfaction with their academic lives, improvement on measures of academic performance, more enterprising vocational interest patterns, and maintenance of higher occupational aspirations.

FLEMING, supra note 83, at 166.

174. Robert B. Davis, Social Support Networks and Undergraduate Student AcademicSuccess-Related Outcomes: A Comparison of Black Students on Black and White Campus$e s$, in COLLEGE IN BLACK AND WHITE 143, 156-57 (Walter R. Allen et al. eds., 1991). 
students on White campuses. In general, the 'fit' between AfricanAmerican students and higher education seems more favorable on historically Black campuses than on predominately White campuses." ${ }^{175}$ As $\mathrm{Du}$ Bois suggested, ${ }^{176}$ predominantly black schools may be better equipped to educate black students.

Moreover, actively integrating universities may otherwise disadvantage black college-bound students by denying some of them the opportunity to attend college at all. Such an effect would result from the current disparity in admissions standards between historically white and historically black schools and could lead to a diminution in the educational opportunities for blacks. Predominantly black public universities tend to have lower admissions standards than predominantly white public universities. ${ }^{177} \mathrm{~A}$ neutral admissions system that would permit only those who meet established requirements to matriculate would likely harm black students because, on average, they tend to score lower on standardized entrance examinations. ${ }^{178}$

If, for example, Delta State Umiversity were merged with predominantly black Mississippi Valley State University (MVSU),

175. Walter R. Allen, The Color of Success: African-American College Student Outcomes at Predominantly White and Historically Black Public Colleges and Universities, 62 HARV. ED. REV. 26, 32 (1992).

176. See supra note 1 and accompanying text.

177. For example, in North Carolina, the five predominantly black public colleges have lower average combined SAT scores for entering freshmen than the predominantly white public colleges in the state. NORTH CAROLINA ALMANAC OF HIGHER EDUCATION 1992, at 68 (1992). At Mississippi's black colleges, the admissions standards were lower than those of the predominantly white schools in part because of the perceived need to keep them within reach of college-bound black students. United States v. Fordice, $112 \mathrm{~S}$. Ct. 2727, 2738-39 (1992).

178. See, e.g., Derrick A. Bell, Jr., Black Colleges and the Desegregation Dilemma, 28 EMORY L.J. 949, 978 (1979) (explaining the increasing number of whites in historically black professional schools by saying, "It is clear that many whites enroll in black colleges, particularly at the professional level, because they are refused admittance into white schools"); Kendall, supra note 88, at 677-78 (discussing the decline in the number of blacks enrolled in Florida's junior colleges after the abolition of black junior colleges in the state); Gail M. Epstein, Note, Desegregation of Public Institutions of Higher Education: Merger as a Remedy, 56 CHI.-KENT L. REv. 701, 726 (1980) (relating the dilemma black colleges face in satisfying constitutional requirements for desegregation without endangering "the valued ... remedial aspects of these schools"); L. Tiffany Hawkins, Note, Recognizing the Nightmare: The Merger of Louisiana State University and Southern University Law Schools, 50 LA. L. REV. 557, 561-62 (1990) (criticizing the proposed merger of a historically white law school and a historically black one on the ground that it would deny a large number of minority applicants the ability to attend law school in the state of Louisiana); see also infra note 180 (describing admissions standards in Mississippi's proposed desegregation plan). 
as the Mississippi plan provides, the problem would arise in this fashion. Because the academic standards to obtain admission are higher at Delta State than at Mississippi Valley, the state governing board would be faced with the alternatives of establishing lower standards for black students, to allow those who would have been admitted to MVSU to get into the merged institution, or maintaining a level standard and admitting only students who meet the higher standards that would result from so many students applying for a scarce resource. ${ }^{179}$ If the state maintains level admissions standards, it likely will be more difficult for black students to gain admission to a college in the unitary system.

Mississippi has tentatively adopted a uniform admissions standard for all its colleges and universities. ${ }^{180}$ In fact, providing different admissions standards for black and white prospective students would appear to violate the established constitutional doctrine limiting affirmative action programs, enunciated in Regents of the University of California v. Bakke ${ }^{181}$ and City of Richmond $v$. J.A. Croson Co. ${ }^{182}$ In Bakke and Croson, the Court limited quotas and stepped standards when the minorities receiving the benefits had not themselves been victimized by specific discriminatory actions and when identifiable whites who had not contributed to or directly benefitted from discriminatory policies were seriously harmed by the preferential policy. ${ }^{183}$ When there is a scarce resource to dole out, usually on the basis of merit, the Court has held that reverse discrimination principles can be invoked to limit the advantage that a minority applicant may have-over a nonminority applicant who has not actively participated in discrimination. ${ }^{184}$

179. Mississippi has chosen the latter alternative. Smothers, supra note 164, at A23.

180. See supra note 179. Under its desegregation plan, students with a 3.2 high school grade point average (GPA), or a $2.5 \mathrm{GPA}$ in a college preparatory curriculum and a 16 score on the ACT, or a 2.0 GPA coupled with an 18 on the ACT would receive automatic admission to any of its colleges. Smothers, supra note 164, at A23. Previously, admission to Mississippi's predominantly black colleges was assured with a score of 13 on the ACT. See Fordice, 112 S. Ct. at 2739.

181. 438 U.S. 265 (1978).

182. 488 U.S. 469 (1989).

183. See DERRICK BELL, RACE, RACISM AND AMERICAN LAW 654-56 (3d ed. 1992); Derrick A. Bell, Jr., Bakke, Minority Admissions, and the Usual Price of Racial Remedies, 67 CAL. L. REV. 3 (1979).

184. See Owen M. Fiss, School Desegregation: The Uncertain Path of the Law, 4 PHIL. \& PUB. AFF. 3, 8-10 (1974). In this article, predating Bakke, Fiss argues that a case such 
An affirmative action plan that would provide for lower admissions standards to Mississippi's colleges, however, established either by Mississippi's legislature or the federal court overseeing the system's desegregation, actually would fit neatly within Bakke's and Croson's exception for remedying past discrimination. Although the Court in Bakke declared that classifications that distinguish "solely because of ... race or ethnic background ... must be regarded as suspect," and thus worthy of heightened scrutiny, ${ }^{185}$ it also implied that such classifications would be acceptable if there has been a determination that the "University engaged in a discriminatory practice requiring remedial efforts." ${ }^{186}$ Croson extended this language, requiring that programs that discriminate on the basis of race must be "fine tun[ed] to [a] remedial purpose" to "pass [constitutional] muster."187 Although the Court struck down the plans in Bakke and Croson, it would appear that any affirmative action project in Mississippi to maintain the number of blacks in college would meet the Court's requirement that it remedy the effects of past discrimination.

Affirmative action plans implemented by Mississippi's integrated colleges may still not address the loss of other potential students who do not wish to attend institutions where racial tension pervades campus life and who therefore would avoid going to college altogether. ${ }^{188}$ Even if the number of black students able to attend college after Mississippi's desegregation plan is implemented remains constant, many black citizens believe that something will be lost if predonimantly black colleges are stripped of their defming characteristic. ${ }^{189}$ Closing these institutions because

as Green, in which the only question is where a student will be assigned to attend school, should be distinguished from a situation in which demand outstrips supply, such as selective admissions to a university due to the scarcity of the resource. But see DeFunis v. Odegaard, 507 P.2d 1169 (Wash. 1973) (en banc) (permitting the University of Washington School of Law to use racial characteristics to provide benefits to minorities, distinguishing benign racial classifications from invidious ones), vacated as moot, 416 U.S. 312 (1974) (per curiam).

185. Bakke, 438 U.S. at 305 . Under the intermediate scrutiny standard that the Court applies to affirmative action programs, the challenged classification must be "necessary to promote a substantial state interest." Id. at 320 (opinion of Powell, J.).

186. Id.

187. City of Richmond v. J.A. Croson Co., 488 U.S. 469, 489 (1989).

188. See Jordan, supra note 169 , at A14.

189. See Alex M. Johnson, Jr., Bid Whist, Tonk, and United States v. Fordice: Why Integration Fails African-American Again, 81 CAL. L. REV. 1401, 1432-68 (1993). Professor Johnson defends the maintenance of predominantly black colleges 
of a misguided understanding of the Constitution's equal protection mandate would be tragic.

\section{B. A Better Way: A Proper Guide to Understanding Real Discrim- ination in Education}

Any evaluation of school policies under the Equal Protection Clause must focus on the provision of equal educational opportunity for all students within the school system. That goal is certainly what the Court had in mind in Brown, what it tried to accomplish in Green, and what it would have state universities achieve after Fordice. ${ }^{190}$ Ultimately, the prohibition of enforced separation of the races in public schools has always been intended to produce equal educational opportunities for all students. The Court's goal in this respect has been to institutionalize that equality by integrating white and black students. By merging formerly dual school systems and ensuring racial balance in schools, however, the Court has favored the results of integration without considering further the potential for equality of opportunity that may exist outside an integrated environment or the inequality that may persist in a racially balanced school.

Undoubtedly, when Chief Justice Warren wrote for the Court in 1954, the segregation of blacks and whites by force of law throughout the Soutli was a badge of inferiority affixed by whites in an effort to retain their superior position in a two-tiered society. When Brown said that separate educational facilities for blacks and whites were inleerently unequal, ${ }^{191}$ it was truly impossible for southern black schools to provide educational opportunities for their students equal to those available at white schools. The massive resistance to integration in the 1950s and 1960s indicated that

for two interrelated reasons. First, the colleges serve as transmitters and preservers of African-American culture, a culture that must be respected if integration is ultimately to succeed. Second, and in a similar vein, the colleges are necessary as a cultural buffer. They provide African-Americans the benefits of the choices of whether or not to "integrate" into mainstream society at all, and when to integrate, now or at a point later in life when they are ready to undertake the arduous transition into a mainstream culture that casts them as the "other."

Id. at 1432 .

190. The basis for all the desegregation decisions has been the premise that, when a state undertakes to provide education to its citizens, it must provide equal educational opportunities for all. More specifically, a state may not deny a person an equal education on the basis of race. See Brown v. Board of Educ., 347 U.S. 483, 493 (1954).

191. Id. at 495. 
the affirmative integrative steps the Court required in Green were necessary to achieve equality in these divided school districts. The chasm between white and black, both in schools and society at large, was so wide that integration appeared to be the only way to achieve real equality. In other words, the declaration that "separate is inherently unequal" reflected reality: the only way to bring the quality of education of blacks up to the level of that of whites was to integrate the schools and eliminate the vestiges of legal segregation "root and branch."192

That shorthand rule, however, which has become the controlling constitutional doctrine for school desegregation, is essentially based on empirical data similar to that used in Brown. ${ }^{193}$ As with any other empirical assertion, the truthfulness of the rule is only as legitimate as the facts supporting it. It seems appropriate now, forty years after legal segregation was held unconstitutional, to unpack the notion that a significant separation of the races presumes inequality for blacks. The time has come to evaluate whether the specific factors that generated inequality when Brown and Green were decided continue to generate such inequality in all circumstances. Rather than presume that a racial imbalance in a school's population, even as a vestige of prior discrimmation, represents a denial of equal protection of the laws, the proper course is to evaluate all the factors involved and specifically deterinine whether this inbalance, even when paired with other inbalances elsewhere, represents a denial of equal educational opportunity to the school's students.

Reevaluating whether racial balance should be the sole criterion of equal opportunity is particularly appropriate in the context of colleges, in which a state typically establishes different institutions with different goals in inind and students make an affirmative decision to attend one school or another. ${ }^{194}$ Colleges and universities are distinguishable from elementary and secondary schools, where the facilities themselves are supposed to be fungible and students typically are assigned to a particular school. No one is assigned to a college, and every student has the opportunity to

192. Green v. County Sch. Bd., 391 U.S. 430, 437-38 (1968).

193. See Brown, 347 U.S. at 494 n.11.

194. See, e.g., United States v. Fordice, 112 S. Ct. 2727, 2736 (1992) ("[L]ike public universities throughout the country, Mississippi's institutions of higher learning are not fungible-they have been designated to perform certain missions. Students who qualify for admission enjoy a range of choices of which institution to attend."). 
seek admittance to any institution. ${ }^{195}$ Although the existence of choice does not erase the state's responsibility to eliminate discrimination, it does suggest that other arbiters, i.e., matriculating students, can make independent determinations that they would receive a roughly equal education at a predominantly black or a predominantly white institution. ${ }^{196}$

These independent student determinations to attend historically black colleges deserve considerable attention given the evidence that historically black colleges represent a viable alternative to predominantly white institutions. Private colleges that have a long tradition of educating black leaders continue to attract top students. ${ }^{197}$ Several empirical studies suggest that blacks are more likely to succeed in environments in which they are in the racial majority. ${ }^{198}$ Racial tensions at predominantly white universities may detract from a focus on academic interests. ${ }^{199}$ A brief survey

195. This proposed revision of desegregation jurisprudence is intended to affect only court-imposed remedies to remove the vestiges of past discrimination by striving to integrate college campuses. This guideline for providing remedies should have no effect on a court's ability to strike down policies that are intended to encourage segregation for the purpose of perpetuating inferior treatment on the basis of race.

196. This assertion assumes, of course, that the choice among colleges is free. If the state corrupts the choice by encouraging different schools for white and black students for the purpose of providing unequal opportunities to blacks, that policy would be a separate constitutional violation. Such discriminatory intent, without facial discrimination, has been held unconstitutional. See, e.g., Village of Arlington Heights v. Metropolitan Hous. Dev. Corp., 429 U.S. 252 (1977); Keyes v. School Dist., 413 U.S. 189 (1973); Yick Wo v. Hopkins, 118 U.S. 356 (1886). But see Personnel Adm'r of Mass. v. Feeney, 442 U.S. 256 (1979) (rejecting a contention that an absolute lifetime preference to veterans invidiously discriminates against women, despite the disproportionate number of male veterans); Washington v. Davis, 426 U.S. 229 (1976) (finding an absence of intent to discriminate on the basis of race, despite black applicants' disproportionately poor scores on a qualifying test for positions as police officers).

197. See supra note 171.

198. See supra notes $\mathbf{1 7 3 - 7 5}$ and accompanying text.

199. The nation's newspaper headlines illustrate the hostility between some white and black students on certain predominantly white college campuses. The University of Pennsylvania has suffered from increasing racial tension; one student was charged with racial harassment for calling five black women "water buffalo," and black students destroyed almost every copy of the student newspaper one day in protest against perceived racism. See Dale Russakoff \& Mary Jordan, At Penn, the Word Divides as Easily as the Sword, WASH. POST, May 15, 1993, at A1. More than a year of protest over the proposed construction of a freestanding black cultural center has consumed the University of North Carolina at Chapel Hill. See Dispute Over Black Center Tears U. of North Carolina, N.Y. TMES, April 21, 1993, at B11. Tensions flared at California State University-Northridge over an alleged boycott by Jewish students of a speech by Louis Farrakhan that was sponsored by the Black Student Union (BSU). The BSU accused the Jewish students of 
of these and other factors demands that Brown's concept of constitutional injury deriving from racial separation be subject to verification in this inodern context.

Given these considerations, a more appropriate test of the adequacy of desegregation remedies would be one in which any racial imbalance among college campuses, even if a vestige of a prior discriminatory system, is not wholly dispositive of the equal protection analysis. The determination whether a predominantly black school is equal to a predominantly white one should involve many of the factors that were implicit in Brown's determination of inherent inequality. Factual findings should be inade to determine whether the value of the education received at such an imstitution is equal to that received at other schools. The state should have the burden of proving to a court that it has satisfied its constitutional duties to eliminate the injurious effects of the de jure segregated regime by showing that predominantly black colleges provide educational opportunities similar to those provided at predominantly white institutions.

Issues may include those assumed as a matter of law in Sweatt v. Painter. ${ }^{200}$ One group of considerations revolves around the actual institutions and whether equivalent amounts of state resources are devoted to predominantly black and predominantly white institutions. To answer that question, courts should evaluate the relative worth of the physical facilities and the amount of space that each institution is able to devote to its educational purpose. An equal amount of money should be allocated to acadeinic endeavors at each school. The salaries of professors, administrators, and staff should be considered as well. The ratio of students to faculty should be roughly equivalent. Another factor is the ainount of funds devoted to scholarships and loan programs. States nay have to give a disproportionate amount of money to historically black colleges to make up for disparities in alumni donations and to ensure that equal funding is provided to each institution. ${ }^{201}$

\footnotetext{
"Hitlerian" tactics in protesting the speech. See John Chandler, CSUN Student Senate Denounces Letter, L.A. TiMES, Nov. 10, 1993, at B7.

200. 339 U.S. 629 (1950); see supra Section I(C).

201. An increase in funding or an upgrade in the quality of programs available at predominantly black schools may lead to de facto integration as white students gravitate to those institutions. This integration could lead to problems concerning the elimination of the distinctive character of a school once characterized by its primarily minority popu-
} 
Another set of factors that courts should evaluate involves the quality of education that students at predommantly black colleges receive. The comparative graduation rates of black students at predominantly black and predominantly white colleges are important. ${ }^{202}$ To determine the relative worth of degrees awarded at the different colleges, courts should consider the success of graduates in competitive employment markets. The continuing success of graduates, i.e., the ability of graduates to achieve high positions in their chosen professions, also may aid courts in their determinations. Courts should examine the depth and breadth of academic programs among colleges with similar inissions, discounting the fact that different programs may be situated at particular colleges to avoid needless duplication. Finally, inquiry should be made to determine the extent of stigmatic injury that persists on predominantly black campuses and whether racial separation still generates a sense of inferiority among black students. If these concerns are adequately met, a state such as Mississippi should constitutionally be able to eliminate discrimination and provide equal educational opportunities to both white and black college students without necessarily balancing the racial composition of each institution's student body and faculty. ${ }^{203}$ As long as these opportunities are truly equal, states should be allowed to provide a wealth of diverse educational environments.

For example, this test for evaluating equality in the provision of equal educational opportunities for white and black students may be used to determine whether Mississippi inust integrate its system of higher education to satisfy its duties under the Fourteenth Amendment. Courts should consider the financial value of the facilities on the campuses and determine whether they are roughly equivalent considering the nissions of the institutions. ${ }^{204}$

lation. For example, at predominantly black Fayetteville State University in Fayetteville, North Carolina, some black students have reacted negatively to whites who have assumed student leadership roles such as drum major of the band and editor of the school newspaper. See White Enrollment Creates Tension at Black College, GreEnsBoro News \& REC., Nov. 15, 1993, at B6.

202. See supra notes $171-75$ and accompanying text.

203. This proposed list of factors is offered by means of illustration only. There are certainly other considerations that a court could evaluate.

204. Certain evidence suggests that Mississippi lags in providing equivalent amounts of resources to its predominantly black institutions. See Brief for Petitioner at 14 n.16, United States v. Mabus, 112 S. Ct. 2727 (1992) (Nos. 90-1205 and 90-6588) (noting that, generally, less money has been invested in the predominantly black universities' physical 
Judges also should evaluate the amount of resources devoted to faculty and staff salaries and to academic programs generally. ${ }^{205}$ A court should compare graduation rates of black students at the predominantly white colleges and universities with student success at Jackson State, Alcorn State, and Mississippi Valley State and then determine whether students at the predominantly black schools are at a disadvantage. ${ }^{206}$ To determine the relative worth of the degrees awarded, a court also should evaluate the ability of graduates of predominantly black colleges to compete for jobs and admission to programs of postgraduate study. To provide a more accurate view of the educational success of the institutions, this comparison may take into account any possible differences in academic preparedness with which black and white students enter college. ${ }^{207}$ Another consideration would be the breadth of academic programs offered at predominantly black schools if such programs substantially duplicate those at predominantly white colleges. Such an evaluation would reveal the academic rigor of the competing institutions. When programs are offered only at predominantly white institutions, a court must satisfy itself that the state is making appropriate efforts to attract minority students to these programs. Courts should not permit a state to drive black students into less desirable careers by offering programs that lead to those careers only at predominantly black schools.

One characteristic of historically black colleges is particularly problematic when evaluating their equahty to predominantly white schools. Black institutions have assumed as part of their mission the effort to provide an education for those students who may not be offered the opportunity elsewhere because of lower grades in high school or lower scores on standardized admission tests. ${ }^{208}$

plants).

205. Mississippi does not appear to devote equal resources to faculty salaries at predominantly black schools. See id. at 12-13 n.14.

206. As noted earlier, predominantly black colleges award a disproportionate number of the degrees earned by black students. See supra note 171. Between 1986 and 1992, more blacks graduated from Mississippi Valley State University than from the University of Mississippi, Delta State University, and the Mississippi University for Women combined. William Raspberry, Pyrrhic Victory, WASH. POST, Jan. 29, 1993, at A23 (quoting Alvin Chambliss, who represented the plaintiffs in Fordice).

207. See supra note 178; infra note 208.

208. See, e.g., Adams v. Richardson, 480 F.2d 1159, 1165 (D.C. Cir. 1973) (en banc) (per curiam) (noting that historically black colleges "fulfill a crucial need" in providing higher education to black students). 
These institutions traditionally have taken on this role because of the substandard treatment that black students have suffered in primary and secondary schools and have assumed the responsibility to expand the higher education opportunities of a group that has been disadvantaged. ${ }^{209}$ As a result, predominantly black colleges generally maintain lower admissions standards than predominantly white schools and often admit more students who fail to meet their criteria than their predominantly white counterparts. ${ }^{210}$

It appears that predominantly black institutions cannot maintain this practice and still clain equality with predominantly white institutions under the rubric this Note proposes. This practice represents a continuance of the history of inferior black institutions that dates from the era of mandatory segregation; maintaining it ensures that predominantly black institutions will not operate on the same level as predominantly white schools that maintain higher admissions standards. If states choose to maintain this practice at all, they would have to require that both historically white and historically black colleges maintain it. Although that may be sensible public policy, a more circunspect concept of equal protection requires that courts consider the historical mission of historically black colleges and their role in providing opportunities for a group that has long been treated unfairly by the public education system. Courts therefore should exclude this practice from determinations of equality between predominantly black and predominantly white colleges and universities. If they refuse to account for this practice of accepting less academically qualified students, courts would be ignoring the discrimination that continues to affect the educational achievement of blacks.

An analogy to the marketplace is appropriate here. A state's system of colleges and universities should nieet the directives of the Equal Protection Clause when a student's choice of school

209. Educators have noted this role. "The institutions had been virtually the only means by which publicly supported higher education was provided to the nation's black population. Generations of black students, suffering from educational deprivation in segregated elementary and secondary schools, found in the colleges an opportunity for higher learning that was not otherwise available." Kujovich, supra note 10, at 36 .

210. For example, in Mississippi all three predominantly black colleges have lower admissions requirements than the five predominantly white institutions. See United States v. Fordice, 112 S. Ct. 2727, 2739 (1992); see also Brief for Petitioner at 16-20, United States v. Mabus, 112 S. Ct. 2727 (1992) (Nos. 90-1205 and 90-6588) (declaring that Mississippi's historically black colleges make more exceptions to the ACT minimum score requirements than its predominantly white schools). 
resembles a free market, i.e., when there are no externalities that improperly influence a student's choice. The Court in Fordice considered the racial identifiability of certain institutions to be such an externality and wrote that the existence of racial identifiability, coupled with past mandatory segregation, requires remedial measures to eliminate it. The time has come, however, to reconsider whether racial identifiability should be deemed an inappropriate externality or a legitimate factor that students may use in deciding where to attend college. Courts should evaluate the real equality of historically black colleges and predommantly white colleges, and then determine whether a state that continues to maintain institutions with their roots in the era of mandatory segregation has succeeded in eliminating the inferiority from that system. Such determinations need not and should not necessarily hinge on the continuing racial identifiability of the institutions. ${ }^{211}$ Separate is no longer inherently unequal.

\section{CONCLUSION}

As society changes, courts must reconsider whether the separation of white and black represents the same kind of burden in 1994 as it did in 1954. If separation does not result in injury, courts should not continue to treat it as if it did, trying to remedy an unconstitutional condition that does not exist. Certainly, the Supreme Court feels compelled to aneliorate racial identifiability, which suggests that it presumes a constitutional violation whenever such identifiability exists and when laws have historically supported segregation. As Fordice extends the Green integration standards to colleges and universities, states that inaintained segregated colleges after 1954 are faced with the burden of proving that their predominantly black colleges do not remain that way as a result of segregative policies. Just as that burden was impossible to meet with freedom-of-choice plans under Green, it appears unlikely that it

211. This Note does not suggest that states are under a constitutional obligation to maintain their predominantly black institutions. State legislatures may decide to integrate all their colleges and universities for any number of reasons, such as their belief that an integrated environment is more appropriate for educating college students. This Note does conclude, however, that courts should not force states to eliminate the racial identifiability of their college campuses on the theory that such identifiability necessarily violates the Equal Protection Clause. 
can be met under Fordice, in a situation where choice also plays an important part in enrollment.

With the prospect of having their university systems declared unconstitutional for maintaining such identifiable institutions, states will have to eliminate such identifiability either by closing colleges entirely or shifting programs so that each school's racial makeup approaches that of the college-bound population. Such a constitutional interpretation forecloses the potentially significant benefits to be gained from maintaining racially diverse college environments and ultimately further burdens the black students whom Brown was intended to help. 


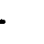

